\section{OAK RIDGE NATIONAL LABORATORY}

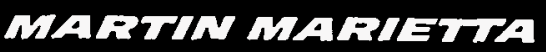

\section{Evaluation of Selected lon} Exchangers for the Removal of Cesium from MVST W-25 Supernate

\author{
J. L. Collins \\ B. Z. Egan \\ K. K. Anderson \\ C. W. Chase \\ J. E. Mrochek \\ J. T. Bell \\ G. E. Jernigan
}

\section{MANAGED BY}

MARTIN MARIETTA ENERGY SYSTEMS, INC.

FOR THE UNITED STATES

DEPARTMENT OF ENERGY
RECEIVED

JUN 191995

CISTRIBUTION OF THIS DOCUMENT IS INIMUTAR S T I 
This report has been reproduced directly from the best available copy.

Available to DOE and DOE contractors from the Office of Scientific and Technical Information, P.O. Box 62, Oak Ridge, TN 37831; prices available from (615) 576-8401, FTS 626-8401.

Available to the public from the National Technical Information Service, U.S. Department of Commerce, 5285 Port Royal Rd., Springfield, VA 22161.

This report was prepared as an account of work sponsored by an agency of the United States Government. Neither the United States Government nor any agency thereof, nor any of their employees, makes any warranty, express or implied, or assumes any legal liability or responsibility for the accuracy, completeness, or usefuiness of any information, apparatus, product, or process disclosed, or represents that its use would not infringe privately owned rights. Reference herein to any specific commercial product, process, or senvice by trade name, trademark, manufacturer, or otherwise, does not necessarily constitute or imply its endorsement, recommendation, or favoring by the United States Government or any agency thereof. The views and opinions of authors expressed herein do not necessarily state or reflect those of the United States Government or any agency thereof. 


\section{DISCLAIMER}

Portions of this document may be illegible in electronic image products. Images are produced from the best available original document. 
Chemical Technology Division

\title{
EVALUATION OF SELECTED ION EXCHANGERS FOR THE REMOVAL OF CESIUM FROM MVST W-25 SUPERNATE
}

J. L. Collins, B. Z. Egan, K. K. Anderson, C. W. Chase, J. E. Mrochek, J. T. Bell," and G. E. Jernigan ${ }^{\dagger}$

"Retired from Martin Marietta Energy Systems, Inc.; formerly a staff member of the ORNL Chemical Technology Division.

'Student of Pellissippi State Technical Community College, Knoxville, Tennessee.

Date Published-April 1995

Prepared for the

U.S. Department of Energy, Office of Technology Development Underground Storage Tank Integrated Demonstration Program

\author{
Prepared by the \\ OAK RIDGE NATIONAL LABORATORY \\ Oak Ridge, Tennessee 37831-6285 \\ managed by \\ MARTIN MARIETTA ENERGY SYSTEMS, INC. \\ for the \\ U.S. DEPARTMENT OF ENERGY \\ under contract DE-AC05-84OR21400
}


0 


\section{CONTENTS}

LIST OF FIGURES $\ldots \ldots \ldots \ldots \ldots \ldots \ldots \ldots \ldots \ldots \ldots \ldots \ldots$

LIST OF TABLES $\ldots \ldots \ldots \ldots \ldots \ldots \ldots \ldots \ldots \ldots \ldots \ldots \ldots \ldots \ldots \ldots \ldots$

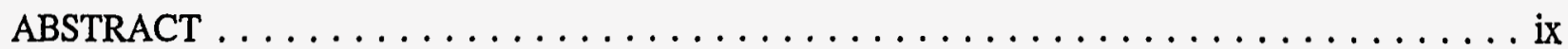

1. INTRODUCTION $\ldots \ldots \ldots \ldots \ldots \ldots \ldots \ldots \ldots \ldots \ldots \ldots \ldots \ldots \ldots \ldots \ldots$

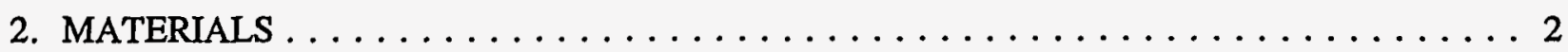

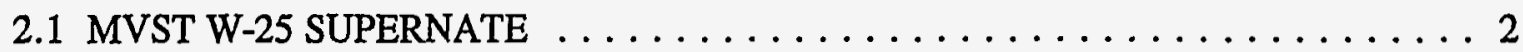

2.2 COMPARISON OF MVST AND HANFORD TANKS $\ldots \ldots \ldots \ldots \ldots \ldots \ldots \ldots$

2.3 ION EXCHANGERS USED TO REMOVE CESIUM FROM MVST W-25

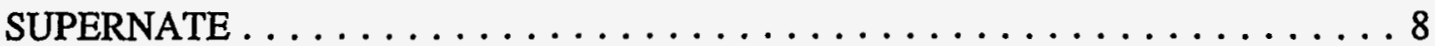

2.3.1 SRR Resorcinol/Formaldehyde Ion-Exchange Resin . . . . . . . . . 8

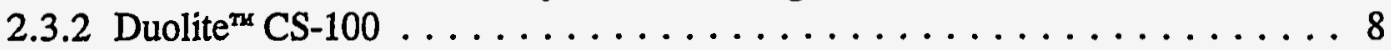

2.3.3 Crystalline Silicotitanates $\ldots \ldots \ldots \ldots \ldots \ldots \ldots \ldots$

2.3.4 Granular Potassium Cobalt Hexacyanoferrate(II) . . . . . . . . . . . . . 9

2.3.5 Hydrous Titanium Oxide/Potassium Cobalt Hexacyanoferrate(II) Composite ....................... 9

2.3.6 Titanium Monohydrogen Phosphate/Sodium Cobalt Hexacyanoferrate(II)

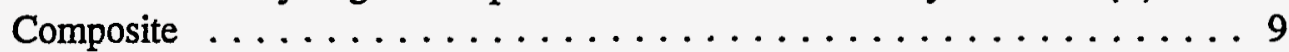

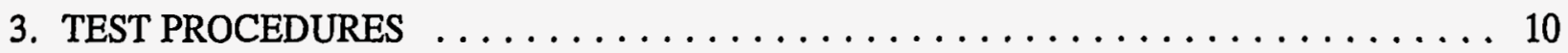

4. CALCUlations $\ldots \ldots \ldots \ldots \ldots \ldots \ldots \ldots \ldots \ldots \ldots \ldots \ldots$

5. TEST RESULTS $\ldots \ldots \ldots \ldots \ldots \ldots \ldots \ldots \ldots \ldots \ldots \ldots \ldots \ldots$

5.1 DISTRIBUTION MEASUREMENTS FOR CESIUM REMOVAL $\ldots \ldots \ldots \ldots \ldots$. . 11

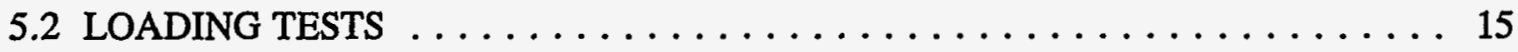

5.2.1 Cesium Loading as a Function of Supernate/Exchanger Ratio and Time . . . 15

5.2.2 Cesium Removal from MVST W-25 Supernate as a Function of Cesium Concentration . . . . . . . . . . . . . . . 17

5.2.3 Effect of $\mathrm{K}$ and $\mathrm{Cs}$ Concentrations on Removing Cs from MVST W-25 Supernate with Sorbents . . . . . . . . . . 27

6. DISCUSSION ............................... 29

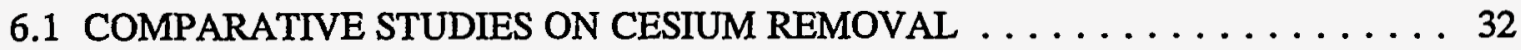

6.2 POTENTIAL APPLICATION TO HANFORD WASTES $\ldots \ldots \ldots \ldots \ldots \ldots \ldots \ldots$

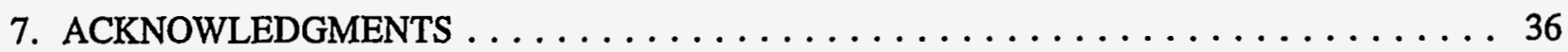

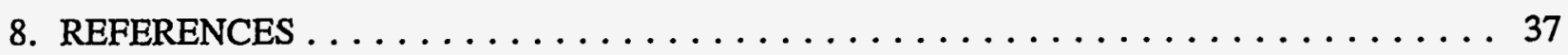

Appendix A. REMOVAL OF ${ }^{137}$ Cs FROM SUPERNATE AT THE LOVIISA NUCLEAR POWER STATION IN HELSINKI, FINLAND . . . . . . . . . . . . 41

Appendix B. PREPARATION OF GRANULAR POTASSIUM COBALT

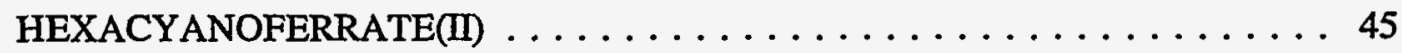




\section{LIST OF FIGURES}

1. Percentage cesium removed by sorbents as a function of mixing time $\ldots \ldots \ldots \ldots$

2. Cesium sorption isotherms using MVST $\mathrm{W}-25$ supernate $\ldots \ldots \ldots \ldots \ldots \ldots$

3. Cesium sorbed on exchangers vs cesium remaining in supernate $\ldots \ldots \ldots \ldots \ldots$

4. Cesium-137 sorbed on exchangers vs that remaining in supernate $\ldots \ldots \ldots \ldots 22$

5. Cesium sorbed on exchangers vs initial cesium concentration in supernate $\ldots \ldots \ldots 23$

6. Cesium sorbed on exchangers vs initial $\mathrm{Na} / \mathrm{Cs}$ mol ratio $\ldots \ldots \ldots \ldots \ldots \ldots$

7. Effect of cesium concentration on the cesium distribution coefficient $\ldots \ldots \ldots \ldots$

8. Effect of potassium concentration on the cesium distribution coefficient $\ldots \ldots \ldots \ldots$

9. Effect of potassium concentration on percentage cesium removed from supernate $\ldots \ldots \ldots 31$

10. Freundlich isotherms for ion exchangers evaluated in this study $\ldots \ldots \ldots \ldots$ 


\section{LIST OF TABLES}

1. Miscellaneous characteristics of the MVST $\mathrm{W}-25$ supernate $\ldots \ldots \ldots \ldots \ldots$

2. Analytical data for MVST $\mathrm{W}-25$ supernate $\ldots \ldots \ldots \ldots \ldots \ldots \ldots \ldots$

3. Analytical data for 17 Hanford tank supernates $\ldots \ldots \ldots \ldots \ldots \ldots$

4. Batch adsorption data showing the effect of mixing time on the removal of

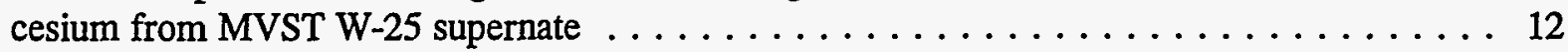

5. Batch adsorption data showing the effect of mixing time on the removal of

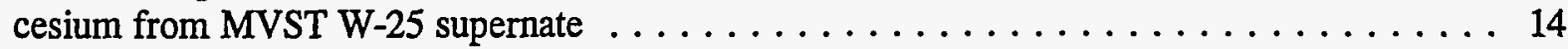

6. Batch adsorption data showing the effects of mixing time and supernate/exchanger ratio on the removal of cesium from MVST $\mathrm{W}-25$ supernate $\ldots \ldots \ldots \ldots$

7. Isotherm data for removing cesium from MVST W-25 supernate with sorbents $\ldots \ldots \ldots 18$

8. Effect of varying the cesium concentration of MVST W-25 supernate on the

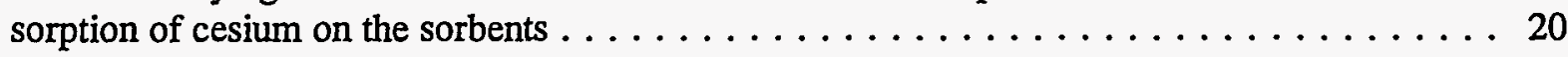

9. Effect of $K$ and $C s$ concentrations on removing Cs from MVST W-25 supernate

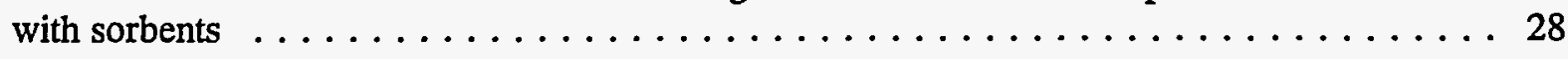

10. Regressed coefficients for the fitting of data to the Freundlich Isotherm Model for three adsorbents 


\begin{abstract}
Bench-scale batch equilibration tests were conducted with an alkaline supernatant (also referred to as supernate) waste $(\mathrm{pH}=12.6$ ) from the Melton Valley Storage Tank (MVST) Facility at Oak Ridge National Laboratory (ORNL) to evaluate the effectiveness of selected ion exchangers, or sorbents, in the removal of radioactive cesium. The radionuclides ${ }^{137} \mathrm{Cs}$ and ${ }^{134} \mathrm{Cs}$ are responsible for most of the gamma activity in the supernatant waste in the underground storage tanks at ORNL, Hanford, and other U.S. Department of Energy (USDOE) sites. The supernate used in this work had a high salt content (3.87 $M$ sodium and $0.36 \mathrm{M}$ potassium) that is similar in composition to some of the supernates stored in underground tanks at other USDOE sites. The sorbents tested were Duolite ${ }^{\mathrm{Tx}}$ CS-100 (a phenolic resin), resorcinol/formaldehyde resin (SRR), crystalline silicotitanate (CST), potassium cobalt hexacyanoferrate $(\mathrm{KCoCF})$, composite microspheres of hydrous titanium oxide (HTiO) that contained $20 \mathrm{wt} \% \mathrm{KCoCF}$, and composite microspheres of titanium monohydrogen phosphate (TiHP) that contained $20 \mathrm{wt} \%$ sodium cobalt hexacyanoferrate $(\mathrm{NaCoCF})$. The order of effectiveness of the sorbents in removing cesium from the supernate was: $\mathrm{KCoCF}>$ (TiHP/NaCoCF microspheres) $>$ (HTiO/KCoCF microspheres) $>\mathrm{CST}>$ SRR > CS-100.

Experiments were also conducted to examine the effect of varying the concentration of cesium in the supernate on the sorption of cesium by SRR, CST, and KCoCF. Results showed that increasing the concentration of total cesium in the supernate from 0.2 to $180 \mathrm{mg} / \mathrm{L}$ had no effect on the distribution coefficients of KCoCF $(-35,000 \mathrm{~mL} / \mathrm{g})$ and CST $(-800 \mathrm{~mL} / \mathrm{g})$. However, the distribution coefficient for the SRR decreased from 560 to $75 \mathrm{~mL} / \mathrm{g}$. For these tests, the $\mathrm{Na}$ and $\mathrm{K}$ concentrations remained constant, but the $\mathrm{Na} / \mathrm{Cs}$ mol ratio was decreased from $2.8 \times 10^{6}$ to $2.8 \times 10^{3}$ and the $\mathrm{K} / \mathrm{Cs}$ mol ratio was decreased from $2.6 \times 10^{5}$ to $2.6 \times 10^{2}$.

Increasing the potassium concentration had little effect on the cesium sorption by CST and KCoCF; however, major decreases in cesium sorption were noted for SRR.
\end{abstract}




\section{INTRODUCTION}

The goal of this batch-test equilibration study was to evaluate the effectiveness of certain ion exchangers for removing cesium from supernate taken from tank W-25 of the Melton Valley Storage Tank (MVST) Facility located at the Oak Ridge National Laboratory (ORNL). ${ }^{1-4}$ These exchangers were selective for removing cesium from alkaline supernatant solutions with high salt concentrations. Since the supernates of evaporator concentrates stored in tanks at the MVST facility have compositions similar to some of those stored in tanks at Hanford, 5,6 the data generated in this study should prove useful in the overall evaluation of the ion exchangers for applications to Hanford and other U.S. Department of Energy (USDOE) sites. This work is a subtask of the Comprehensive Demonstration of Sludge and Supernate Processing Program (CDSSPP).

Liquid low-level wastes (LLLWs) that are generated at the ORNL site are concentrated in an LLW evaporator. The evaporator concentrates are stored in 12 stainless steel, 50,000-gal tanks-8 at the MVST facility and 4 at the evaporator facility. As of March 1994, when samples of sludge and supernate were taken from tank W-25 for use in this study, the operators at the MVST site estimated that the combined volume of waste contained in the 8 tanks at the MVST site was 287,000 gal; the assiociated supernate volume was estimated at 175,000 gal. The volume of waste in the 4 tanks at the evaporator facility was 138,000 gal. The estimated volume of supernate in tank W-25 was $\sim 19,500$ gal.

At the Hanford site, there are 177 underground tanks containing wastes with different compositions. The total volume stored in these tanks is estimated at 60 million gallons with a radioactivity level of $>200 \mathrm{MCi}$. Major contributors to the radioactivity are $\mathrm{Cs}$ and $\mathrm{Sr}$, and the major actinides are $\mathrm{U}, \mathrm{Pu}$, and Am. The radionuclides ${ }^{137} \mathrm{Cs}$ and ${ }^{90} \mathrm{Sr}$ are responsible for contributing $97 \%$ of the beta-gamma activity. Cesium-137 is the major contributor to the activity of the supernates. 5,6

A goal of the waste processing effort at Hanford is to remove enough cesium to ensure that the resulting LLW will meet the Nuclear Regulatory Commission (NRC) 10 CFR 61 class A limit for ${ }^{137} \mathrm{Cs}$ $\left(1 \mathrm{Ci} / \mathrm{m}^{3}\right.$ or $\left.1 \mu \mathrm{Ci} / \mathrm{mL}\right)$. The separated cesium may be concentrated and vitrified for disposal in the highlevel waste repository. The decontaminated effluent would be solidified for near-surface disposal..$^{6,7}$ 


\section{MATERIALS}

\subsection{MVST W-25 SUPERNATE}

The supernate stock solution used in the batch tests was sampled directly from the supernate layer in MVST W-25 in March 1994. Approximately $2 \mathrm{~L}$ of the supernate was prepared for use by passing it through $0.45-\mu \mathrm{m}$ nylon filters to remove any particulates. The specific gravity and the total solids content of the filtered supernate were $1.232 \mathrm{~g} / \mathrm{mL}$ and $0.388 \mathrm{~g} / \mathrm{mL}$, respectively; the $\mathrm{pH}$ was 12.6 . Table 1 compares the specific gravity, total solids, and $\mathrm{pH}$ for the supernate in this study with the corresponding values obtained for supernate samples taken from MVST W-25 in December 1989 in a study conducted by Sears et al. ${ }^{1}$ As shown, each of the values for the supernate in the present study is slightly higher. Because the tank was air-sparged during the 4.5-year period between samplings to concentrate the supernate by vaporization, these differences are reasonable. Air-sparging tends to mix the supernate but provides little mixing of the sludge layer solids or the sludge with the supernate. Thus, the system was assumed to be nonequilibrated. According to the operators at the MVST facility, no additional evaporator concentrate or other liquid was added to the W-25 tank during that period.

Table 1. Miscellaneous characteristics of the MVST W-25 supernate

\begin{tabular}{ccc}
\hline & \multicolumn{2}{c}{ MVST W-25 supernate } \\
\cline { 2 - 3 } Property & Present study & Sears et al. $^{\mathrm{a}}$ \\
\hline Total solids, $\mathrm{g} / \mathrm{mL}$ & 0.388 & 0.344 \\
Specific gravity, g/mL & 1.232 & 1.202 \\
$\mathrm{pH}$ & 12.62 & 12.50 \\
\hline
\end{tabular}

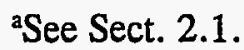

A comparison of the concentrations of the radionuclides in the supernate in the present study with the values obtained by Sears et al. ${ }^{1}$ is provided in Table 2. (The latter values have been corrected for the 4.5-year decay period.) In the present study, which is denoted by CDSSPP in Table 2, samples of the supernate were analyzed for radionuclide content in both the Chemistry and Analytical Sciences Division (CASD) and the Chemical Development Section (CDS) of the Chemical Technology Division. About 
Table 2. Analytical data for MVST W-25 supernate

\begin{tabular}{|c|c|c|c|c|c|}
\hline \multirow[b]{2}{*}{ Component } & \multicolumn{3}{|c|}{ Supernate } & \multicolumn{2}{|c|}{ Sludge liquid } \\
\hline & $\begin{array}{l}\text { Sears"- } \\
\text { CASD }\end{array}$ & $\begin{array}{c}\text { CDSSPPc- } \\
\text { CDS }^{d}\end{array}$ & $\begin{array}{c}\text { CDSSPP- } \\
\text { CASD }\end{array}$ & $\begin{array}{c}\text { CDSSPP- } \\
\text { CDS }\end{array}$ & $\begin{array}{c}\text { CDSSPP- } \\
\text { CASD }\end{array}$ \\
\hline \multicolumn{6}{|c|}{ Radionuclides, Bq/L } \\
\hline${ }^{134} \mathrm{Cs}$ & $8.3 E+05$ & $7.4 \mathrm{E}+06$ & $6.5 \mathrm{E}+05$ & 3.7E+06 & $2.6 \mathrm{E}+06$ \\
\hline${ }^{137} \mathrm{Cs}$ & $2.9 \mathrm{E}+08$ & $2.3 E+08$ & $2.5 \mathrm{E}+08$ & $1.3 E+08$ & $1.1 \mathrm{E}+08$ \\
\hline${ }^{\infty} \mathrm{Co}$ & $1.0 \mathrm{E}+06$ & $6.3 E+06$ & $6.4 \mathrm{E}+05$ & $6.2 \mathrm{E}+05$ & $1.7 E+05$ \\
\hline${ }^{14} \mathrm{Eu}$ & $B D L^{e}$ & $1.1 E+05$ & BDL & $1.0 \mathrm{E}+05$ & BDL \\
\hline${ }^{9} \mathrm{Sr}$ & $1.8 \mathrm{E}+07$ & $\mathrm{NM}^{\mathrm{e}}$ & $1.0 \mathrm{E}+06$ & NM & $2.0 \mathrm{E}+08$ \\
\hline${ }^{99} \mathrm{Tc}$ & NM & NM & $2.1 \mathrm{E}+04$ & NM & NM \\
\hline \multicolumn{6}{|c|}{ Other metals, mg/L } \\
\hline Al & BDL & & 453 & & \\
\hline B & 0.6 & & BDL & & \\
\hline $\mathrm{Ba}^{\prime}$ & 3.2 & & 1.2 & & \\
\hline $\mathrm{Ca}$ & 280 & & 9.5 & & \\
\hline $\mathrm{Cr}^{8}$ & 1.9 & & 51 & & \\
\hline Cs & NM & & 0.19 & & \\
\hline $\mathrm{Hg}^{\prime}$ & 0.05 & & BDL & & \\
\hline $\mathrm{K}^{\mathbf{2}}$ & 17,000 & & 14,000 & & \\
\hline $\mathrm{Na}^{\mathrm{B}}$ & 78,000 & & 89,000 & & \\
\hline $\mathrm{Ni}^{\mathrm{l}}$ & 0.45 & & BDL & & \\
\hline $\mathrm{Sr}$ & 23 & & 0.4 & & \\
\hline $\mathrm{Tc}$ & NM & & 0.032 & & \\
\hline Th & $\mathrm{BDL}$ & & 0.3 & & \\
\hline $\mathbf{U}$ & BDL & & 4.3 & & \\
\hline $\mathbf{Z n}$ & BDL & & 9.5 & & \\
\hline \multicolumn{6}{|l|}{ Anions, mg/L } \\
\hline $\mathrm{Cl}^{-}$ & 2,500 & & 3,740 & & \\
\hline F & BDL & & 371 & & \\
\hline $\mathrm{NO}_{3}^{-}$ & 260,000 & & 236,000 & & \\
\hline $\mathrm{SO}_{4}^{2 .}$ & BDL & & 2,370 & & \\
\hline
\end{tabular}

-The Sears el al. data for the radionuclides have been corrected for 4.5-year decay.

'Samples were counted by the Chemistry and Analytical Sciences Division (CASD).

cComprehensive Demonstration of Sludge and Supernate Processing Program (CDSSPP).

¿Samples were counted in the Chemical Development Section of the Chemical Technology Division.

${ }^{\circ} \mathrm{BDL}=$ below detection limit; $\mathrm{NM}=$ not measured.

RCRA metals.

sSears - 3.39 $M \mathrm{Na}$ and $0.44 M \mathrm{~K}$; CDSSPP - 3.87 $M \mathrm{Na}$ and $0.36 M \mathrm{~K}$. 
$94 \%$ of the activity in the supernate is contributed by ${ }^{137} \mathrm{Cs}$. The values obtained for ${ }^{137} \mathrm{Cs}$ concentration by the CASD and the CDS showed good agreement, $2.5 \times 10^{8}$ and $2.3 \times 10^{8} \mathrm{~Bq} / \mathrm{L}$, respectively. The value obtained by Sears et al. was $2.9 \times 10^{8} \mathrm{~Bq} / \mathrm{L} .{ }^{1}$ On the other hand, the values obtained for ${ }^{134} \mathrm{Cs}$ and ${ }^{60} \mathrm{Co}$ by the CASD and CDS were not in good agreement: the ones obtained by the CASD were an order of magnitude lower. The values obtained by the CDS are probably more accurate because the samples were counted for a much longer period ( $20 \mathrm{~h}$ as compared with $0.5 \mathrm{~h}$ ). The counts were near the detection limit, and the longer counting times provided better statistics. The ${ }^{90} \mathrm{Sr}$ values obtained for the supernate samples from the study by Sears et al. (i.e., $1.8 \times 10^{7} \mathrm{~Bq} / \mathrm{L}$ ) and the ones obtained for the present study $\left(1.0 \times 10^{6} \mathrm{~Bq} / \mathrm{L}\right)$ differ by an order of magnitude. One possible explanation that might account for this discrepancy is the difference in particulate contents. The supernate samples in the present study were filtered through $0.45-\mu \mathrm{m}$ nylon filters before they were analyzed; the Sears et al. samples were not filtered. It appears that $-94 \%$ of the ${ }^{90} \mathrm{Sr}$ was removed by the filtration step. The concentration of ${ }^{99} \mathrm{Tc}$ was $2.0 \times 10^{4} \mathrm{~Bq} / \mathrm{L}$.

The concentrations of radionuclides in samples of decanted sludge liquid were also determined by both the CDS and the CASD (see results in Table 2). To obtain the sludge liquid, samples of the W-25 sludge stock used in the sludge characterization and dissolution studies were first centrifuged and the liquid removed by decantation. The concentration of ${ }^{137} \mathrm{Cs}$ in the sludge liquid was only one-half of that in the supernate. The ${ }^{60} \mathrm{Co}$ concentrations were about equal. Conversely, the ${ }^{90} \mathrm{Sr}$ content in the sludge liquid was 200 times that in the supernate. The sludge liquid also was filtered with a $0.45-\mu \mathrm{m}$ nylon filter before analysis. No batch tests have been conducted with the sludge liquid thus far.

Table 2 also gives a comparison of the concentrations of the other metals and anions in the Sears et al. ${ }^{1}$ and CDSSPP supernates. These data show that the major cations in the MVST W-25 supernate samples are $\mathrm{Na}^{+}$and $\mathrm{K}^{+}$while the major anions are $\mathrm{NO}_{3}^{-}$and $\mathrm{Cl}^{-}$. The concentrations of $\mathrm{Na}$ and $\mathrm{K}$ for the Sears et al. supernate were 3.39 and $0.44 M$, respectively, with a $\mathrm{Na} / \mathrm{K}$ mol ratio of $7.7 .^{1}$ For the CDSSPP supernate, the $\mathrm{Na}$ and $\mathrm{K}$ concentrations were 3.87 and $0.36 \mathrm{M}$, respectively; the $\mathrm{Na} / \mathrm{K}$ mol ratio was 10.8. These differences in concentrations and mol ratios were probably the result of (1) the 4.5 years of air-sparging of MVST W-25 between samplings and (2) the locations at which the samples were withdrawn from the tank. The lower $\mathrm{Ca}(280 \mathrm{vs} 9.5 \mathrm{mg} / \mathrm{L}), \mathrm{Ba}(3.2 \mathrm{vs} 1.2 \mathrm{mg} / \mathrm{L}$ ), and $\mathrm{Sr}$ (23 vs $0.4 \mathrm{mg} / \mathrm{L}$ ) concentrations in the CDSSPP sample may have resulted because the CDSSPP supernate was filtered with a $0.45-\mu \mathrm{m}$ nylon filter before analysis. The $\mathrm{Al}, \mathrm{Cr}, \mathrm{Th}, \mathrm{U}$, and $\mathrm{Zn}$ concentrations were higher in the CDSSPP sample, especially the $\mathrm{Al}$ (BDL vs $453 \mathrm{mg} / \mathrm{L}$, or $0.017 \mathrm{M}$ ) and $\mathrm{Cr}(1.9 \mathrm{vs} 51 \mathrm{mg} / \mathrm{L}$, 
or $0.01 \mathrm{M}$ ). The $\mathrm{NO}_{3}{ }^{-}$concentration determined for the CDSSPP supernate was 3.8 $\mathrm{M}$ as compared with the Sears et al. value of $4.19 \mathrm{M}$; the $\mathrm{Cl}^{-}$was slightly higher at $0.1 \mathrm{M}$ vs $0.07 \mathrm{M}$ obtained by Sears et al. ${ }^{1}$

The ranges of concentrations in the supernates for the eight tanks at the MVST facility reported by Sears et al. ${ }^{1}$ were 2.7 to $4.8 M$ for $\mathrm{Na}, 0.24$ to $2.0 \mathrm{M}$ for $\mathrm{K}$, and 0.00001 to $0.57 \mathrm{M}$ for $\mathrm{Ca}$. The average concentrations for the tanks were $3.8 M \mathrm{Na}, 0.6 \mathrm{M} \mathrm{K}, 0.08 \mathrm{M} \mathrm{Ca}$, and $0.0005 M \mathrm{Al}$. The average $\mathrm{Na} / \mathrm{K}$ mol ratio was 6.3; the highest mol ratio was 19 , and the lowest was 2 .

Since cesium-selective ion exchangers remove both radioactive $\left({ }^{137} \mathrm{Cs}\right.$, ${ }^{134} \mathrm{Cs}$, and $\left.{ }^{135} \mathrm{Cs}\right)$ and nonradioactive $\left({ }^{133} \mathrm{Cs}\right)$ isotopic cations of cesium, it was important to determine the total cesium concentration of the MVST W-25 supernate. This value, which was determined by graphite-furnace atomic absorption analysis by the CASD to be $0.19 \mathrm{mg} / \mathrm{L}\left(1.4 \times 10^{-6} \mathrm{M}\right)$, is consistent with the calculated concentration of total cesium based on fission yield calculations using the ORIGEN computer program. ${ }^{8}$ The total mass of fission product cesium in light-water reactor spent fuel for a decay period ranging from 0 to 30 years would be in the range of 2.4 to 3 times the mass of ${ }^{137} \mathrm{Cs}$. The additional cesium is composed of ${ }^{135} \mathrm{Cs}\left(\mathrm{t}_{1 / 2}=2.0 \times 10^{6}\right.$ years) and nonradioactive ${ }^{133} \mathrm{Cs}$, which are decay products of ${ }^{135} \mathrm{Xe}$ and ${ }^{133} \mathrm{Xe}$, respectively. By dividing the ${ }^{137} \mathrm{Cs}$ activity $(6.8 \mathrm{mCi} / \mathrm{L})$ for the tank $\mathrm{W}-25$ supernate by the specific activity for ${ }^{137} \mathrm{Cs}\left(87 \mathrm{mCi} / \mathrm{mg}\right.$ ), the average mass of ${ }^{137} \mathrm{Cs}$ per liter was calculated to be about $0.08 \mathrm{mg}$. The minimum concentration of cesium in the supernate was found to be between 0.19 and $0.24 \mathrm{mg} / \mathrm{L}$ $\left(\sim 1.6 \times 10^{-6} \mathrm{M}\right)$ of supernate, which is in good agreement with the analyzed value. At the start of the program, it was assumed that normal cesium might have been added to the tank. However, the analytical results suggest that this was not the case.

The concentrations of total carbon (TC) and inorganic carbon (IC) in the filtered MVST W-25 supernate were determined by the CASD using a Dohrmann DC-90 Carbon Analyzer. The TC and IC were $2113 \pm 28$ and $310 \pm 28 \mathrm{mg} / \mathrm{L}$, respectively. The total organic carbon (TOC) was determined by difference $(\mathrm{TOC}=\mathrm{TC}-\mathrm{IC}$ ) to be $1803 \pm 38 \mathrm{mg} / \mathrm{L}$.

\subsection{COMPARISON OF MVST AND HANFORD TANKS}

For comparative information, the ranges of concentrations for $\mathrm{Na}, \mathrm{K}$, and $\mathrm{Al}$ in the 17 Hanford double-shell tanks as reported by Colton et al. ${ }^{5}$ were 0.09 to $14.7 M, 0.001$ to $1.1 M$, and 0.0001 to $2.4 M$ (see Table 3). The Ca concentrations were $\leq 0.007 M$ for the four tanks that were analyzed. Seven tanks have Na concentrations $26.4 M$; the remaining tanks have concentrations $s 4 M$. Concentrations of $\mathrm{K}$ are given for 14 of the 17 tanks. Two tanks have concentrations $\geq 0.86 M$, while the others are $s 0.39 M$ 
Table 3. Analytical data for 17 Hanford tank supernates ${ }^{2}$

\begin{tabular}{|c|c|c|c|c|c|c|c|}
\hline \multirow[b]{2}{*}{ Tank number } & \multicolumn{5}{|c|}{ Concentration $(M)$} & \multicolumn{2}{|c|}{ Mol ratio } \\
\hline & $\mathrm{Na}$ & K & $\mathrm{Al}$ & $\mathrm{Ca}$ & $\mathrm{Cs}^{\mathrm{b}}$ & $\mathrm{Na} / \mathrm{Cs}$ & $\mathrm{K} / \mathrm{Cs}$ \\
\hline AN-103 & 14.65 & 0.39 & 2.14 & $2.0 \mathrm{E}-03$ & $1.6 \mathrm{E}-04$ & $9.2 \mathrm{E}+04$ & $2.4 \mathrm{E}+03$ \\
\hline SY-103 & 13.78 & 0.14 & 2.40 & $7.0 \mathrm{E}-03$ & $2.0 \mathrm{E}-07$ & $7.1 E+07$ & $7.2 E+05$ \\
\hline SY-101 & 12.20 & 0.13 & 1.65 & $\mathrm{NR}^{c}$ & $1.5 \mathrm{E}-04$ & $8.1 E+04$ & $8.6 \mathrm{E}+02$ \\
\hline AN-104 & 12.06 & 0.18 & 1.40 & NR & $2.0 \mathrm{E}-04$ & $6.2 \mathrm{E}+04$ & $9.1 \mathrm{E}+02$ \\
\hline AN-105 & 11.94 & 0.16 & 1.73 & NR & $1.3 \mathrm{E}-04$ & $9.2 \mathrm{E}+04$ & $1.2 \mathrm{E}+03$ \\
\hline AW-101 & 10.02 & 1.07 & 1.04 & 8.0E-04 & $1.4 \mathrm{E}-04$ & $7.5 \mathrm{E}+04$ & $8.2 \mathrm{E}+03$ \\
\hline AP-105 & 6.36 & 0.86 & 0.16 & $1.0 \mathrm{E}-03$ & $6.7 \mathrm{E}-05$ & $9.6 \mathrm{E}+04$ & $1.3 \mathrm{E}+04$ \\
\hline AN-106 & 4.09 & 0.03 & 0.34 & $2.0 \mathrm{E}-03$ & $4.8 \mathrm{E}-05$ & $8.5 \mathrm{E}+04$ & $6.3 \mathrm{E}+02$ \\
\hline AZ-101 & 2.43 & 0.06 & 1.03 & $8.0 \mathrm{E}-05$ & $6.6 \mathrm{E}-04$ & $3.7 \mathrm{E}+03$ & $9.1 \mathrm{E}+01$ \\
\hline AZ-102 & 2.22 & 0.04 & 0.004 & $2.0 \mathrm{E}^{\prime}-04$ & $1.9 \mathrm{E}-04$ & $1.2 \mathrm{E}+04$ & $2.1 \mathrm{E}+02$ \\
\hline AW-106 & 1.74 & 0.33 & 0.02 & NR & $1.3 \mathrm{E}-05$ & $1.3 \mathrm{E}+05$ & $2.5 \mathrm{E}+04$ \\
\hline AP-106 & 1.07 & 0.11 & 0.11 & $3.0 \mathrm{E}-03$ & $9.3 \mathrm{E}-06$ & $1.2 \mathrm{E}+05$ & $1.2 \mathrm{E}+04$ \\
\hline AW-105 & 1.02 & NR & 0.02 & $1.0 \mathrm{E}-03$ & $1.2 \mathrm{E}-05$ & $8.4 \mathrm{E}+04$ & \\
\hline AW-103 & 0.97 & 0.34 & 0.003 & $1.0 \mathrm{E}-04$ & $7.5 \mathrm{E}-06$ & $1.3 \mathrm{E}+05$ & $4.5 \mathrm{E}+04$ \\
\hline AW-102 & 0.73 & NR & 0.02 & NR & $3.9 \mathrm{E}-06$ & $1.9 E+05$ & \\
\hline AP-103 & 0.23 & NR & 0.01 & NR & $1.7 \mathrm{E}-06$ & $1.4 \mathrm{E}+05$ & \\
\hline AY-102 & 0.09 & 0.001 & 0.0001 & $1.0 \mathrm{E}-04$ & $1.0 \mathrm{E}-06$ & $9.0 \mathrm{E}+04$ & $1.0 \mathrm{E}+03$ \\
\hline MVST W-25 & 3.87 & 0.36 & 0.02 & $2.4 \mathrm{E}-04$ & $1.4 \mathrm{E}-06$ & $2.8 \mathrm{E}+06$ & $2.6 \mathrm{E}+05$ \\
\hline
\end{tabular}

${ }^{2}$ N. G. Colton, R. G. Orth, and E. A. Aitken, Tank Waste Processing Analysis: Database Development, Tankby-Tank Processing Requirements, and Examples of Pretreatment Sequences and Schedules as Applied to Hanford Double-shell Tank Supernatant Waste-FY 1993, PNL-10134, September 1994.

'For each tank, the mass of total cesium used in the molar concentration calculation was obtained by multiplying the mass of the ${ }^{137} \mathrm{Cs}$ by 3 (see Sect. 2.2).

${ }^{\mathrm{C}} \mathrm{NR}=$ not reported.

${ }^{d}$ Analysis of the ORNL MVST W-25 supernate for comparison. 
(nine of those are $\leq 0.18 M$ ). Seven tanks have Al concentrations $\geq 1 M$; the other tanks have concentrations $\leq 0.34 M$ (nine of which are $s 0.16 M$ ). The average concentrations for the 17 tanks were $5.6 M \mathrm{Na}$, $0.27 M \mathrm{~K}, 0.71 M \mathrm{Al}$, and $0.0001 M \mathrm{Ca}$. For tanks where both the $\mathrm{Na}$ and the $\mathrm{K}$ concentrations were given, the $\mathrm{Na} / \mathrm{K}$ mol ratios ranged from 2.9 to 136 ; the average mol ratio was 52 . The second largest $\mathrm{Na} / \mathrm{K}$ mol ratio was only 90 . The average was about eight times larger than the average for the eight MVSTs. ${ }^{1}$ These data show that the concentrations of $\mathrm{K}$ and $\mathrm{Ca}$ in the MVSTs are generally higher than those for the 17 Hanford tanks, but the concentrations of $\mathrm{Na}$ and $\mathrm{Al}$ are higher in the Hanford tanks.

For the batch-test equilibration study, it should be noted that the presence of $\mathrm{K}$ ions in the supernate can have a much larger effect than $\mathrm{Na}$ ions on the removal of $\mathrm{Cs}$ by ion exchangers. ${ }^{6}$ Ion exchangers that are selective for $\mathrm{Cs}$ in either basic or acidic solutions with high concentrations of $\mathrm{Na}$ also have a high affinity for $\mathrm{K}$ ions, which limits the amounts of $\mathrm{Cs}$ that can be sorbed.

The range of ${ }^{137} \mathrm{Cs}$ concentrations for the 17 Hanford tanks is much greater, ${ }^{5}$ from 0.7 to $2500 \mathrm{mCi} / \mathrm{L}$, with an average concentration of $405 \mathrm{mCi} / \mathrm{L}$. The next highest concentration of ${ }^{137} \mathrm{Cs}$ in a tank is $750 \mathrm{mCi} / \mathrm{L}$. If the $2500-\mathrm{mCi} / \mathrm{L}$ tank is not included in the average, then the average concentration for the remaining tanks would be decreased to $272 \mathrm{mCi} / \mathrm{L}$. Eight of the tanks have ${ }^{137} \mathrm{Cs}$ concentrations in the range of 180 to $750 \mathrm{mCi} / \mathrm{L}$. On the low side, eight of the tanks have ${ }^{137} \mathrm{Cs}$ concentrations between 0.7 and $51 \mathrm{mCi} / \mathrm{L}$; three of them are in the range of 0.7 to $7 \mathrm{mCi} / \mathrm{L}$. If a decay period of 30 years is assumed, and if all of the cesium in the 17 Hanford tanks is fission product derived, then the calculated average concentration of total cesium in the 17 Hanford tanks would be $-14 \mathrm{mg} / \mathrm{L}\left(1.0 \times 10^{-4} \mathrm{M}\right)$. The total cesium concentrations ranged from $0.024 \mathrm{mg} / \mathrm{L}\left(2.8 \times 10^{-7} \mathrm{M}\right)$ to $86.2 \mathrm{mg} / \mathrm{L}\left(6.6 \times 10^{-4} \mathrm{M}\right)$. The ${ }^{137} \mathrm{Cs}$ concentrations ${ }^{1}$ for the MVSTs ranged between 5 and $56 \mathrm{mCi} / \mathrm{L}$; however, 7 of the 8 tanks have ${ }^{137} \mathrm{Cs}$ concentrations in the range of 5 to $9 \mathrm{mCi} / \mathrm{L}$.

The ranges of the $\mathrm{Na} / \mathrm{Cs}$ and $\mathrm{K} / \mathrm{Cs}$ mol ratios for the Hanford tanks were $3.7 \times 10^{3}$ to $7.1 \times 10^{7}$ and 91 to $7.2 \times 10^{5}$, respectively, with corresponding averages of $4.3 \times 10^{6}$ and $5.9 \times 10^{4}$. If the tank with a very low Cs concentration $(0.0007 M)$ were excluded, the averages would be much lower, $9.3 \times 10^{4}$ and $8.2 \times 10^{3}$. The ranges of $\mathrm{Na} / \mathrm{Cs}$ and $\mathrm{K} / \mathrm{Cs}$ mol ratios for the six tanks with high concentrations of $\mathrm{Na}$ $(z 10 M)$ and $\mathrm{K}(20.13 \mathrm{M})$ were $6.2 \times 10^{4}$ to $7.1 \times 10^{7}$ and $8.6 \times 10^{2}$ to $7.2 \times 10^{5}$, respectively. For the other 11 Hanford tanks, where the concentrations of $\mathrm{Na}$ were $s 6.4 \mathrm{M}$ and the concentrations of $\mathrm{K}$ were $\leq 0.34 \mathrm{M}$, the ranges of $\mathrm{Na} / \mathrm{Cs}$ and $\mathrm{K} / \mathrm{Cs}$ mol ratios were $3.7 \times 10^{3}$ to $1.3 \times 10^{5}$ and 91 to $4.5 \times 10^{4}$, respectively; the corresponding averages were $9.8 \times 10^{4}$ and $1.2 \times 10^{4}$. The $\mathrm{Na} / \mathrm{Cs}$ and $\mathrm{K} / \mathrm{Cs} \mathrm{mol}$ ratios 
for the MVST W-25 were $2.6 \times 10^{6}$ and $2.4 \times 10^{5}$, respectively. Only one of the Hanford tanks had mol ratios as large.

\subsection{ION EXCHANGERS USED TO REMOVE CESIUM FROM MVST W-25 SUPERNATE}

The ion exchangers evaluated in this study are known to be effective in sorbing cesium from alkaline saline solutions such as the supernates located in the storage tanks at ORNL and Hanford. ${ }^{34,6,9,10}$ The following subsections provide a description of the materials that have been tested or are scheduled to be tested. Any preliminary treatment given them is described in detail.

\subsubsection{SRR Resorcinol/Formaldehyde Ion-Exchange Resin}

SRR is a resorcinol/formaldehyde resin that was developed at the Savannah River Site.,4,6,9,11-13 The resin used in this study had a particle size of 35 to 28 mesh ( 425 to $595 \mu \mathrm{m}$ ); it was prepared by the Boulder Scientific Company. One set of tests was conducted with the resin "as received." A second set was conducted with resin that had been washed twice with ten resin volumes of $2 M$ formic acid, twice with ten volumes of $0.25 \mathrm{M} \mathrm{NaOH}$, and, finally, three times with ten volumes of distilled water. In a third set, the resin was washed several times with $2 \mathrm{M} \mathrm{NaOH}$, followed by washing several times with deionized water. Batch tests to determine cesium removal were conducted with each of these materials. Only the results obtained by using the "as received" resin are provided in this report. Analytical data for the treated resins showed no significant improvement.

\subsubsection{Duolite $^{\text {Tx }}$ CS-100}

Duolite ${ }^{\text {th }} \mathrm{CS}-100$ is a cesium-selective phenolic resin ${ }^{2,4,6}$ that has been manufactured commercially by Rohm and Haas, Inc. A sieve size of 35 to 28 mesh ( 425 to $595 \mu \mathrm{m}$ ) was used. One set of Duolite ${ }^{\text {Ts }}$ CS-100 resin samples was tested as received. A second set was given the same formic acid/NaOH pretreatment as the SRR resin, but the pretreatment had no significant effect on the cesium sorption.

\subsubsection{Crystalline Silicotitanates}

Crystalline silicotitanates (CSTs) are a new class of inorganic ion exchangers invented and developed through a collaborative effort between Sandia National Laboratories (SNL) and Texas A\&M University. ${ }^{6,1416}$ The CST identified as lot DG-114 was prepared under the same conditions as lots DG$111,-112,-113,-114$, and -115 ; it is the base-line composition provided to many DOE laboratories. ${ }^{17}$ 
This material was supplied by N. E. Brown of SNL as part of an Efficient Separations and Processing Integrated Program (ESP-IP) to evaluate the effectiveness of CSTs for removing cesium and other radionuclides from DOE radwastes. The composition of CST is proprietary, and no information on the specifics of CST synthesis or composition was provided. The CST provided is a very fine powder that could be used in a batch process but is not suitable for use in an ion-exchange column. An engineered form is being developed by UOP, Des Plaines, Illinois, under a Cooperative Research and Development Agreement with SNL. It is projected that the engineered form will be commercially available in mid-1995 from UOP. ${ }^{17}$

\subsubsection{Granular Potassium Cobalt Hexacyanoferrate(II)}

Granular potassium cobalt hexacyanoferrate $[\mathrm{KCoCF}(\mathrm{gr})]$ is an inorganic ion exchanger that is selective for cesium ions in alkaline saline solutions. Plant-scale column experiments ${ }^{18,19}$ conducted at the Loviisa NPA Plant in Helsinki, Finland, demonstrated that it was very effective in removing cesium from alkaline supernatant solution containing $2.6 \mathrm{M} \mathrm{Na}, 0.26 \mathrm{M} \mathrm{K}, 5.6 \mathrm{M} \mathrm{B}$, and $2.7 \times 10^{-9} M \mathrm{Cs}$. The granular KCoCF used in that work was developed and produced at the Loviisa site; the material was made using a modification of the patented procedure developed by W. P. Prout et al..$^{20,21}$ for making granular KCoCF. Detailed information and a discussion about this work are provided in Appendix A. The KCoCF used in the present study was prepared at ORNL using the procedure described in the Prout et al. patent, ${ }^{20}$ with a slight modification. Since the material was prepared at ORNL and is not available commercially, a discussion of the preparative procedure is given in Appendix B.

\subsubsection{Hydrous Titanium Oxide/Potassium Cobalt Hexacyanoferrate(II) Composite}

Hydrous titanium oxide/potassium cobalt hexacyanoferrate(II) composite (HTiO/KCoCF) was prepared as microspheres by the internal gelation process. ${ }^{22}$ The hydrous titanium oxide (HTiO) microspheres were homogeneously embedded with very fine $\mathrm{K}_{2} \mathrm{CoFe}(\mathrm{CN})_{6}$ powder $(-20 \mathrm{wt} \%)$. The diameter of the microspheres used in the batch tests ranged from 250 to $495 \mu \mathrm{m}$. The uniqueness of this

exchanger is that it is prepared in a column-usable form (as microspheres) and the HTiO effectively removes strontium from alkaline solutions of high salt content. The development of the engineered composite microspheres has been described by Collins et al. ${ }^{9}$

\subsubsection{Titanium Monohydrogen Phosphate/Sodium Cobalt Hexacyanoferrate(II) Composite}

Titanium monohydrogen phosphate/sodium cobalt hexacyanoferrate(II) composite (TiHP/NaCoCF) was first prepared as HTiO/NaCoCF microspheres by the internal gelation method. ${ }^{9,22}$ The HTiO matrix material was converted to titanium monohydrogen phosphate (TiHP) by pressurized heating of composite 
$\mathrm{HTiO} / \mathrm{NaCoCF}$ microspheres with phosphoric acid solutions. The diameter of the microspheres ranged from 250 to $495 \mu \mathrm{m}$. The TiHP effectively sorbs strontium from akaline solutions of high salt content.

\section{TEST PROCEDURES}

The sorption measurements were made using batch equilibration tests. The supernate and the exchangers were contacted in 15-mL, screw-cap, polypropylene centrifuge tubes by mixing with a Labquake $^{\mathrm{Tx}}$ shaker. The action of the mixer is a back-and-forth rocking motion that was set to rock from $-45^{\circ}$ to $+45^{\circ}$ from the horizontal plane at $\sim 20$ cycles per minute. The exchangers and the supernate were weighed in consecutive steps into tared tubes. The volumes of supernate (normally about $10 \mathrm{~mL}$ ) were calculated from the specific gravity of the supernate. At the end of the equilibration periods, the tubes were reweighed to determine if any leakage had occurred. The tubes were then centrifuged for $30 \mathrm{~min}$ at $3000 \mathrm{rpm}$ with an International Equipment Company Centra 7 tabletop centrifuge. Afterward, $\sim 2-\mathrm{mL}$ volumes of the clarified supernates were transferred to clean centrifuge tubes by pipet and again centrifuged for $30 \mathrm{~min}$. With a syringe filtering system, the clarified supernates were filtered successively through $0.45-\mu \mathrm{m}$ and $0.2-\mu \mathrm{m}$ nylon filters to remove any of the remaining fine particulates. Samples $(0.5 \mathrm{~mL})$ of the filtered supernate were pipetted into counting tubes for radiochemical analysis. The ${ }^{137} \mathrm{Cs}$ activity was determined using an LKB Wallac 1282 Compugamma Universal Gamma Counter. Postequilibration $\mathrm{pH}$ measurements were made on each sample using an ORION Research Digital pH Meter and an ORION 8103 ROSS combination electrode. The electrode was calibrated with $\mathrm{pH} 7$ and $\mathrm{pH} 10$ buffer solutions. Duplicate samples were run. Control tests were also run; $10-\mathrm{mL}$ samples of supernate were added to $15-\mathrm{mL}$ propropylene centrifuge tubes and mixed for 2,24 , and $72 \mathrm{~h}$. No detectable change in the ${ }^{137} \mathrm{Cs}$ activity of the supernate was noted.

Sorption data for equilibration times of $0.25,2,24,72$, and $144 \mathrm{~h}$ were determined for each exchanger tested. Each test used $0.050 \mathrm{~g}$ of exchanger and a supernate volume of $10 \mathrm{~mL}$, giving a solution/solid ratio of $200 / 1$. In tests with the $\mathrm{HTiO} / \mathrm{NaCoCF}$ or TiHP/KCoCF microspheres, the mass of microspheres was increased to $-0.175 \mathrm{~g}$ to contain $\sim 0.050 \mathrm{~g}$ of NaCoCF or KCoCF. The matrix materials, HTiO and TiHP, do not sorb cesium from alkaline saline solutions, but they do sorb strontium. Equilibration isotherms and kinetic data were determined by varying the masses of exchangers from 0.100 to $0.005 \mathrm{~g}$ while maintaining constant supernate volumes $(10 \mathrm{~mL})$ for mixing times of 0.25 to $144 \mathrm{~h}$. 


\section{CALCUlations}

Results of batch tests are reported as percentage removal (\% R), distribution ratio (D), and decontamination factor (DF). These values are calculated in the following manner:

$$
\begin{aligned}
& \% \mathrm{R}=100\left[\left(C_{0}-C_{\mathrm{J}}\right) / C_{0}\right], \\
& \mathrm{D}=\left[\left(C_{\mathrm{o}}-C_{\mathrm{\nu}} / C_{\mathrm{v}}\right][V / m] \text { (units are } \mathrm{mL} / \mathrm{g}\right), \\
& \mathrm{DF}=C_{\mathrm{o}} / C_{\mathrm{t}} .
\end{aligned}
$$

The pretest and posttest count rates of ${ }^{137} \mathrm{Cs}$ are denoted by $C_{\mathrm{o}}$ and $C_{\mathrm{t}}$, respectively. The $\mathrm{D}$ is an expression of the ratio of concentration of a radionuclide sorbed on the ion exchanger to the concentration remaining in the test solution after a specified mixing time, where $V$ is the volume of supernate and $m$ is the mass of exchanger.

\section{TEST RESULTS}

\subsection{DISTRIBUTION MEASUREMENTS FOR CESIUM REMOVAL}

Table 4 and Fig. 1 give the results of batch tests to measure the rate of cesium adsorption with CS100 , SRR, CST, and KCoCF(gr) ion exchangers. The SRR and CS-100 materials were used as received. In each test, as described in Sect. 3, $0.050 \mathrm{~g}$ of exchanger was mixed with $10 \mathrm{~mL}$ of MVST W-25 supernate for $0.25,2,24,72$, or $144 \mathrm{~h}$.

The highest cesium removal was obtained with $\mathrm{KCoCF}(\mathrm{gr})$. The range of $\mathrm{D}$ values was 26,000 to $46,200 \mathrm{~mL} / \mathrm{g}$; the percentage removal (\% R) range was 99.3 to 99.6 . CS-100 was the least effective in removing cesium; the highest $\mathrm{D}$ and $\% \mathrm{R}$ values were $44 \mathrm{~mL} / \mathrm{g}$ and 22 , respectively. SRR and CST were similar in sorbing Cs from the supernate, with the D values ranging from 138 to $764 \mathrm{~mL} / \mathrm{g}$ for the SRR and 451 to $958 \mathrm{~mL} / \mathrm{g}$ for the CST. After $144 \mathrm{~h}$ of mixing, the SRR and CST removed 78.7 and $83.8 \%$ of the Cs, respectively. In the shorter, 0.25 -h tests, CST removed $71.5 \%$, and the SRR removed $41 \%$ of the Cs. This is not surprising because the CST is a fine powder and has more surface area that is readily available for cesium adsorption. After 2 - $h$ mixing time, the $\% \mathrm{R}$ values for CST and SRR were about equal. Under these test conditions, the $\mathrm{KCoCF}(\mathrm{gr})$ was the most effective exchanger and its kinetics were the most rapid.

Table 5 gives a comparison of the adsorption of cesium using several KCoCF materials, including composite material made as microspheres by the internal gelation process (see Sects. 2.3.5 and 2.3.6). In each of these batch tests, $10 \mathrm{~mL}$ of MVST W-25 supernate was mixed with $0.050 \mathrm{~g}$ of KCoCF. Each 
Table 4. Batch adsorption data showing the effect of mixing time on the removal of cesium from MVST W-25 supernate ${ }^{\mathrm{a}}$

\begin{tabular}{|c|c|c|c|c|c|c|c|c|c|c|c|c|c|c|c|}
\hline \multirow[b]{3}{*}{ Exchanger ${ }^{b}$} & \multicolumn{15}{|c|}{ Mixing time (h) } \\
\hline & \multicolumn{3}{|c|}{$(0.25)$} & \multicolumn{3}{|c|}{ (2) } & \multicolumn{3}{|c|}{ (24) } & \multicolumn{3}{|c|}{ (72) } & \multicolumn{3}{|c|}{ (144) } \\
\hline & $\begin{array}{c}\mathrm{D} \\
(\mathrm{mL} / \mathrm{g})\end{array}$ & $\mathscr{~} \mathrm{R}$ & $\mathrm{pH}$ & $\begin{array}{c}D \\
(\mathrm{~mL} / \mathrm{g})\end{array}$ & $\% R$ & $\mathrm{pH}$ & $\begin{array}{c}\mathrm{D} \\
(\mathrm{mL} / \mathrm{g})\end{array}$ & $\% R$ & $\mathrm{pH}$ & $\begin{array}{c}D \\
\left(m L_{g}\right)\end{array}$ & $\% R$ & $\mathrm{pH}$ & $\begin{array}{c}\text { D } \\
(\mathrm{mL} / \mathrm{g})\end{array}$ & $\% R$ & $\mathrm{pH}$ \\
\hline CS-100 & 34 & 15.3 & 12.2 & 35 & 20.0 & 12.2 & 34 & 15.0 & 12.2 & 42 & 20.0 & 12.6 & 44 & 22.0 & 12.6 \\
\hline SRR & 138 & 41.0 & 12.6 & 763 & 79.3 & 12.6 & 736 & 79.5 & 12.6 & 764 & 79.2 & 12.6 & 641 & 78.7 & 12.6 \\
\hline CST & 451 & 71.5 & 12.6 & 662 & 77.4 & 12.6 & 672 & 77.5 & 12.6 & 672 & 77.7 & 12.6 & 958 & 83.8 & 12.6 \\
\hline $\mathrm{KCoCF}(\mathrm{gr})$ & 36,900 & 99.5 & 12.3 & 46,200 & 99.6 & 12.3 & 36,900 & 99.5 & 12.3 & 36,300 & 99.5 & 12.2 & 26,000 & $99.3^{\circ}$ & 12.2 \\
\hline
\end{tabular}

${ }^{2}$ Each batch test was conducted by mixing $50 \mathrm{mg}$ of adsorber with $10 \mathrm{~mL}$ of MVST W-25 supernate for the times indicated. The initial cesium concentration in the supernate was $0.19 \mu \mathrm{g} / \mathrm{mL}$.

${ }^{\text {bSRR }}=$ resorcinol/formaldehyde resin $(425$ to $595 \mu \mathrm{m}) ; \mathrm{CST}=$ crystalline silicotitanate (fine powder); and $\mathrm{KCoCF}(\mathrm{gr})=$ granular potassium cobalt hexacyanoferrate $(250$ to $595 \mu \mathrm{m})$. 


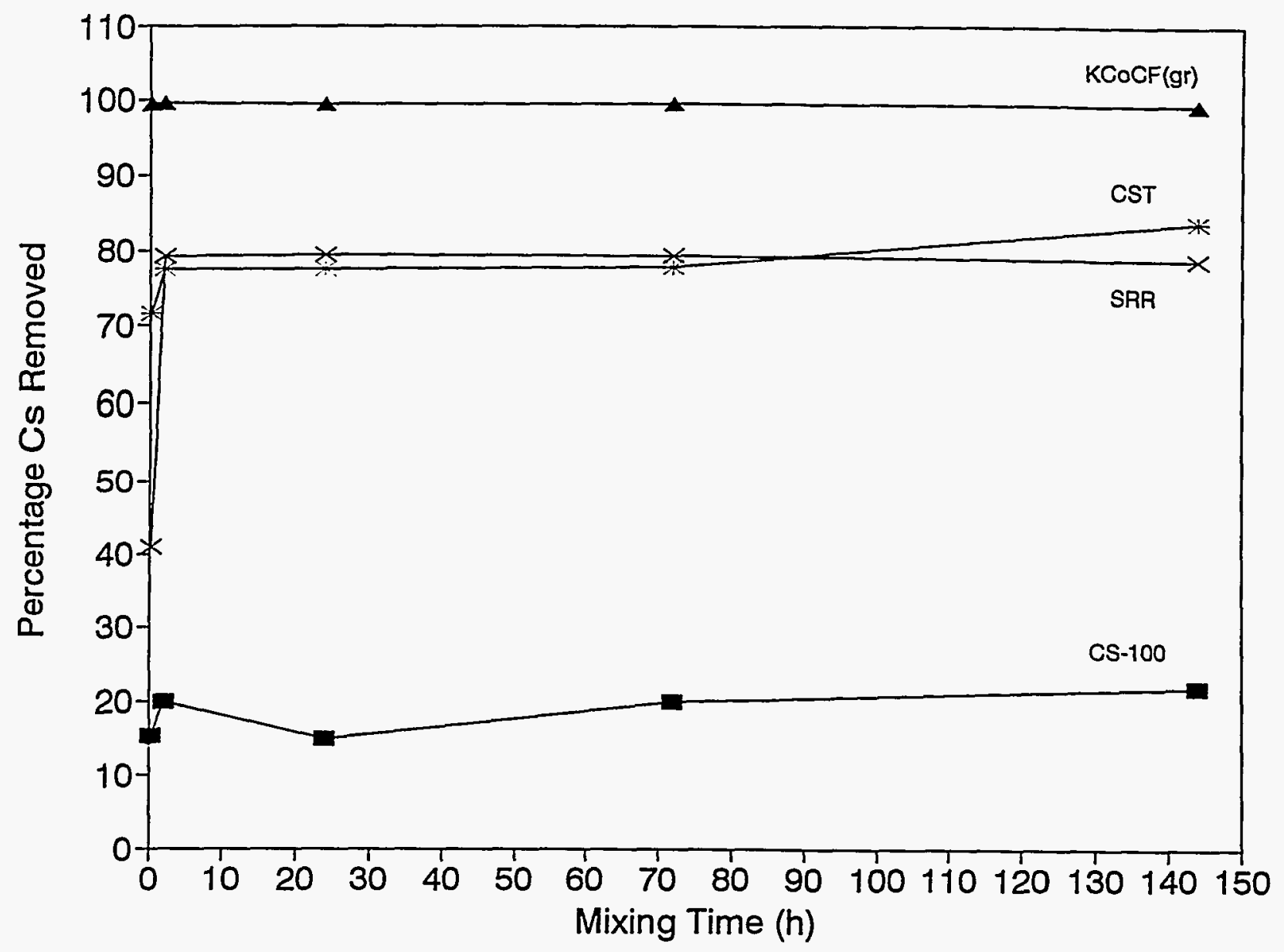

Fig. 1. Percentage cesium removed by sorbents as a function of mixing time. 
Table 5. Batch adsorption data showing the effect of mixing time on the removal of cesium from MVST W-25 supernate ${ }^{\mathrm{a}}$

\begin{tabular}{|c|c|c|c|c|c|c|c|c|c|c|c|c|c|c|c|}
\hline \multirow[b]{3}{*}{ Exchangers } & \multicolumn{15}{|c|}{ Mixing time (h) } \\
\hline & : & $(0.25)$ & $\because$ & & (2) & & & (24) & & & (72) & & & (144) & \\
\hline & $\begin{array}{l}\mathrm{D} \\
(\mathrm{mL} / \mathrm{g})\end{array}$ & \% R & $\mathrm{pH}$ & $\begin{array}{c}\text { D } \\
(\mathrm{mL} / \mathrm{g})\end{array}$ & $\% R$ & $\mathrm{pH}$ & $\begin{array}{cc}\quad \text { D } \\
:(m L / g)\end{array}$ & $\% \mathrm{R}$ & $\mathrm{pH}$ & $\begin{array}{c}D \\
(\mathrm{~mL} / \mathrm{g})\end{array}$ & $\mathscr{6} \mathrm{R}$ & $\mathrm{pH}$ & $\begin{array}{c}D \\
(\mathrm{~mL} / \mathrm{g})\end{array}$ & $\% R$ & $\mathrm{pH}$ \\
\hline $\mathrm{KCOCF}(\mathrm{fp})$ & $\vdots$ & & & 49,900 & 99.6 & 12.3 & 66,800 & 99.7 & 12.3 & 18,630 & 99.0 & 12.2 & 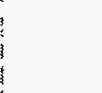 & & \\
\hline $\mathrm{KCoCF}(\mathrm{gr})$ & 36,900 & 99.5 & 12.3 & 46,200 & 99.6 & 12.3 & 36,900 & 99.5 & 12.3 & 36,300 & 99.5 & 12.2 & 26,000 & 99.3 & 12.2 \\
\hline TiHP/NaCoCF & & & & 1,140 & 96.9 & 9.4 & 3,105 & 98.8 & 9.4 & 3,960 & 99.1 & 9.4 & 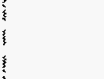 & & \\
\hline HTIO/KCOCF & & & & 110 & 72.3 & 12.3 & 5,550 & 99.3 & 12.3 & 5,500 & 99.3 & 12.3 & 5,530 & 99.3 & 12.3 \\
\hline
\end{tabular}

${ }^{a}$ With the exception of the composite microspheres, each batch test was conducted by mixing $50 \mathrm{mg}$ of adsorber with $10 \mathrm{~mL}$ of tank W-25 supernate for the times indicated. For the composite microspheres, the masses of microspheres that contained $50 \mathrm{mg}$ of the $\mathrm{NaCoCF}$ or $\mathrm{KCoCF}$ were used. The initial concentration of cesium in the supernate was $0.19 \mu \mathrm{g} / \mathrm{mL}$.

${ }^{b} \mathrm{KCoCF}(\mathrm{fp})=$ potassium cobalt hexacyanoferrate ion exchanger (fine powder); $\mathrm{KCoCF}(\mathrm{gr})=$ granular form, 250 to $595 \mu \mathrm{m}$; TiHP/NaCoCF $=$ titanium monohydrogen phosphate microspheres containing $\sim 20 \mathrm{wt} \%$ sodium cobalt hexacyanoferrate; and HTiO/KCoCF = hydrous titanium oxide microspheres containing $-20 \mathrm{wt} \% \mathrm{KCoCF}(\mathrm{gr})$. 
test with microspheres used a mass of microspheres that contained $0.050 \mathrm{~g}$ of embedded $\mathrm{KCoCF}$ or $\mathrm{NaCoCF}$. Separate tests with titanium monohydrogen phosphate and hydrous titanium oxide microspheres (250 to $600 \mu \mathrm{m}$ ) were also conducted. These materials without the embedded hexacyanoferrates removed $<5 \%$ of the cesium from the MVST W-25 supernate after mixing times of 2 and $72 \mathrm{~h}$. The microspheres that contained $\mathrm{KCOCF}$ or $\mathrm{NaCoCF}$ removed $>70 \%$ of the cesium in $2 \mathrm{~h}$. For the longer mixing times, the percentages of cesium removed were similar to the values obtained by using $K C \operatorname{CoF}(\mathrm{gr})$. The $\mathrm{D}$ values obtained for the microspheres containing hexacyanoferrate were lower because larger total masses were in the tests. If only the mass $(0.050 \mathrm{~g})$ of the embedded $\mathrm{KCoCF}$ or $\mathrm{NaCoCF}$ were used in the calculation of the $D$ values, the $D$ values would be similar to those obtained for the $K C \operatorname{CF}(\mathrm{gr})$. In the 2-h tests, only $72 \%$ of the cesium was removed by the HTiO/KCoCF microspheres, as compared with $96.6 \%$ for the TiHP/NaCoCF microspheres. However, for the longer mixing times, the percentage removal by the HTiO/KCoCF microspheres increased. Diffusion of cesium ions into the matrix of the microspheres seems to be enhanced by increased hydration. The HTiO microspheres exhibited more swelling in aqueous solution than did the TiHP microspheres, but the swelling of the HTiO occurred more slowly. In the tests with the $\mathrm{KCOCF}$ powder, the cesium removal values were higher.

\subsection{LOADING TESTS}

\subsubsection{Cesium Loading as a Function of Supernate/Exchanger Ratio and Time}

Parallel cesium adsorption tests were conducted with SRR, CST, and $\mathrm{KCoCF}(\mathrm{gr})$ ion exchangers using 210- to 595- $\mu \mathrm{m}$ material and a supernate/exchanger (S/E) ratio that was varied from $2000 / 1$ to $100 / 1$ $(\mathrm{mL} / \mathrm{g})$. This was accomplished by using a constant volume of supernate $(10 \mathrm{~mL})$ and varying the mass of ion exchanger from 0.005 to $0.1 \mathrm{~g}$. The S/E used for the SRR and CST tests covered the range of $1000 / 1$ to $100 / 1$; an S/E range of $2000 / 1$ to $200 / 1$ was examined for $\mathrm{KCoCF}(\mathrm{gr}$ ) because it showed higher cesium sorption. Measurements were made for $0.25,2,24,72$, and $144 \mathrm{~h}$; the results are summarized in Table 6.

For equilibration tests conducted for $144 \mathrm{~h}$, the D values for cesium from MVST W-25 supernate ranged from 562 to $1400 \mathrm{~mL} / \mathrm{g}$ for SRR, 615 to $958 \mathrm{~mL} / \mathrm{g}$ for CST, and 26,200 to $75,600 \mathrm{~mL} / \mathrm{g}$ for $\mathrm{KCoCF}$ (gr). The cesium \% R ranged from 63.2 to 87.3 for SRR, 49.0 to 90.9 for CST, and 96.9 to 99.4 for $\mathrm{KCoCF}$ (gr). The best DF values were 7.7 for SRR, 11 for CST, and 167 for $\mathrm{KCoCF}$ (gr).

For tests conducted for the shortest equilibration time period $(0.25 \mathrm{~h})$, the $\mathrm{D}$ values for cesium removal from the supernate ranged from 84 to $293 \mathrm{~mL} / \mathrm{g}$ for SRR, 297 to $505 \mathrm{~mL} / \mathrm{g}$ for CST, and 330 
Table 6. Batch adsorption data showing the effects of mixing time and supernate/exchanger ratio on the removal of cesium from MVST W-25 supernate ${ }^{a}$

\begin{tabular}{|c|c|c|c|c|c|c|c|c|c|c|c|c|}
\hline \multirow[b]{3}{*}{ Exchanger } & \multirow{3}{*}{\multicolumn{2}{|c|}{$\begin{array}{c}S / E^{c} \\
(\mathrm{~mL} / \mathrm{g})\end{array}$}} & \multicolumn{10}{|c|}{ Mixing time (h) } \\
\hline & & & \multicolumn{2}{|c|}{$(0.25)$} & \multicolumn{2}{|c|}{ (2) } & \multicolumn{2}{|c|}{ (24) } & \multicolumn{2}{|c|}{ (72) } & \multicolumn{2}{|c|}{ (144) } \\
\hline & & & $\underset{(\mathrm{mL} / \mathrm{g})}{\mathrm{D}}$ & 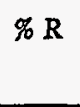 & $\underset{(\mathrm{mL} / \mathrm{g})}{\mathrm{D}}$ & $\% \mathrm{R}$ & $\underset{(\mathrm{mL} / \mathrm{g})}{\mathrm{D}}$ & $\% \mathrm{R}$ & $\underset{(\mathrm{mL} / \mathrm{g})}{\mathrm{D}}$ & $\% \mathrm{R}$ & $\begin{array}{c}\mathrm{D} \\
(\mathrm{mL} / \mathrm{g})\end{array}$ & $\% \mathrm{R}$ \\
\hline SRR & 1000 & 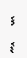 & 293 & 24.1 & 370 & 28.9 & 1,500 & 63.4 & 1,500 & 63.4 & 1,400 & 63.2 \\
\hline SRR & 400 & ; & 227 & 33.0 & 315 & 45.0 & 1,070 & 75.4 & 1,170 & 76.5 & 1,080 & 76.1 \\
\hline SRR & 200 & $\vdots$ & 138 & 41.0 & 763 & 79.3 & 736 & 79.5 & 764 & 79.2 & 641 & 78.7 \\
\hline SRR & 100 & 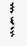 & 84 & 45.7 & 459 & 82.6 & 597 & 85.8 & 619 & 87.0 & 562 & 87.3 \\
\hline CST & 1000 & 3 & 505 & 32.6 & 652 & 39.5 & 1,120 & 55.3 & 1,020 & 54.9 & 615 & 49.0 \\
\hline CST & 400 & & 337 & 47.8 & 477 & 55.4 & 744 & 68.6 & 643 & 66.6 & 616 & 67.1 \\
\hline CST & 200 & 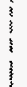 & 451 & 71.5 & 662 & 77.4 & 672 & 77.5 & 672 & 77.7 & 958 & 83.8 \\
\hline CST & 100 & 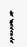 & .297 & 73.8 & 321 & 77.2 & 686 & 88.5 & 976 & 91.2 & 843 & 90.9 \\
\hline $\mathrm{KCoCF}(\mathrm{gr})$ & 2000 & i & 1,240 & 37.8 & 29,800 & 93.9 & 68,400 & 97.5 & 68,400 & 97.6 & 48,400 & 96.9 \\
\hline $\mathrm{KCoCF}(\mathrm{gr})$ & 1000 & ; & 630 & 65.0 & 17,200 & 95.0 & 31,300 & 97.2 & 59,700 & 98.5 & 75,600 & 98.7 \\
\hline $\mathrm{KCoCF}(\mathrm{gr})$ & 400 & $\stackrel{\leftrightarrow}{:}$ & 330 & 83.3 & 44,000 & 99.2 & 58,400 & 99.3 & 19,300 & 98.2 & 54,500 & 99.4 \\
\hline $\mathrm{KCoCF}(\mathrm{gr})$ & 200 & 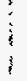 & 36,900 & 99.5 & 46,200 & 99.6 & 36,900 & 99.5 & 36,200 & 99.5 & 26,200 & 99.3 \\
\hline
\end{tabular}

'Each batch test was conducted by mixing either $5,10,25,50$, or $100 \mathrm{mg}$ of adsorber with $10 \mathrm{~mL}$ of MVST W-25 supernate for the time indicated. The initial concentration of cesium in the supernate was $0.19 \mu \mathrm{g} / \mathrm{mL}$.

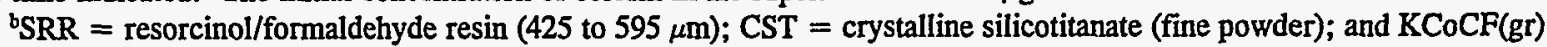
$=$ granular potassium cobalt hexacyanoferrate $(210$ to $595 \mu \mathrm{m})$.

${ }^{\mathrm{c}} \mathrm{S} / \mathrm{E}=$ ratio of volume of supernate to mass of ion exchanger. 
to 36,900 for $\mathrm{KCoCF}(\mathrm{gr})$. The cesium \% $\mathrm{R}$ ranged from 24.1 to 45.7 for SRR, 32.6 to 73.8 for $\mathrm{CST}$, and 37.8 to 99.5 for $\mathrm{KCoCF}(\mathrm{gr})$. The best DF values were 1.8 for SRR, 3.8 for CST, and 200 for $\mathrm{KCoCF}(\mathrm{gr})$. Cesium was removed faster with the CST than with the SRR, but the rate was highest for the granular $\mathrm{KCoCF}$. The maximum cesium sorption on $\mathrm{KCoCF}(\mathrm{gr})$ was achieved after $24 \mathrm{~h}$, and then the sorption decreased; the maximum cesium sorption on SRR and CST occurred after $72 \mathrm{~h}$ before decreasing.

Table 7 gives the isotherm data for removing cesium from MVST W-25 supernate with the sorbents for mixing periods of $\geq 24 \mathrm{~h}$. These data are plotted in Fig. 2. Results are also included from two additional 24-h batch tests in which CST and granular KCoCF were mixed at an S/E ratio of 5000/1 (about $2 \mathrm{mg}$ sorbent was mixed with $10 \mathrm{~mL}$ of supernate). In those tests, 92 and $27 \%$ of the cesium were removed by the granular $\mathrm{KCOCF}$ and CST, respectively. The corresponding $\mathrm{D}$ values were 51,800 and $1800 \mathrm{~mL} / \mathrm{g}$.

The maximum cesium sorbed under these conditions was $5.8 \mathrm{meq} / \mathrm{kg}$ for $\mathrm{KCoCF}(\mathrm{gr}), 0.9 \mathrm{meq} / \mathrm{kg}$ for SRR, and $1.9 \mathrm{meq} / \mathrm{kg}$ for CST. There were no breaks in the loading curves in Fig. 2 for any of the exchangers. Ion-exchange column tests are needed to determine the cesium loading capacities for these sorbents with the MVST W-25 supernate.

\subsubsection{Cesium Removal from MVST W-25 Supernate as a Function of Cesium Concentration}

Batch tests were conducted to determine the effect of varying the cesium concentration of MVST W-25 supernate on the sorption of cesium by the ion exchangers SRR, CST, and KCoCF. The goal was to simulate the Hanford supernates by using samples of tank W-25 supernate where the concentrations of cesium were adjusted. As was described in Sect. 1, the Hanford supernates have wide ranges of $\mathrm{Na}, \mathrm{K}$, and Cs concentrations. The range of Cs concentration was 0.024 to $86 \mathrm{mg} / \mathrm{L}$.

The results of the batch tests are given in Table 8 and in Figs. 3-7. A $7.52 \times 10^{-2} \mathrm{M} \mathrm{CsCl}$ stock solution $\left({ }^{133} \mathrm{Cs}\right.$ only) was used to obtain cesium concentrations of 0.19 to $726 \mathrm{mg} / \mathrm{L}$, giving $\mathrm{Na} / \mathrm{Cs} \mathrm{mol}$ ratios of $6.6 \times 10^{2}$ to $2.8 \times 10^{6}$ and $\mathrm{K} / \mathrm{Cs}$ mol ratios of $6.1 \times 10^{1}$ to $2.6 \times 10^{5}$. The Na and $\mathrm{K}$ concentrations were 3.87 and $0.36 \mathrm{M}$, respectively. The additions of the stable Cs stock solution to the supernate samples only slightly lowered the concentrations of $\mathrm{Na}$ and $\mathrm{K}$. In each test, $\sim 50 \mathrm{mg}$ of exchanger was mixed with $\sim 5 \mathrm{~mL}$ of supernate for $\sim 24 \mathrm{~h}$ at room temperature.

For these test conditions, Table 8 shows that the maximum cesium sorbed by the different exchangers was $11 \mathrm{~g} / \mathrm{kg}$ for SRR, $50 \mathrm{~g} / \mathrm{kg}$ for CST, and $71 \mathrm{~g} / \mathrm{kg}$ for $\mathrm{KCoCF}(\mathrm{gr})$. The ranges of distribution coefficients (mL/g) for the exchangers were 45 to 560 for SRR, 226 to 970 for CST, and 5,000 to 37,400 for $\mathrm{KCoCF}(\mathrm{gr})$. The percentages of cesium removed from the supernate samples (\% $\mathrm{R})$ ranged from 31 
Table 7. Isotherm data for removing cesium from MVST W-25 supernate with sorbents ${ }^{\mathrm{a}}$

\begin{tabular}{|c|c|c|c|c|c|c|}
\hline Sorbent $t^{b}$ & $S / E^{c}$ & $\begin{array}{r}\text { Cs loading } \\
\text { (meq } / \mathrm{kg} \text { ) }\end{array}$ & $\begin{array}{c}{[\mathrm{Cs}]} \\
(\mathrm{meq} / \mathrm{L})\end{array}$ & $\begin{array}{c}\mathrm{D} \\
(\mathrm{mL} / \mathrm{g})\end{array}$ & $\% \mathrm{R}$ & $\mathrm{DF}$ \\
\hline \multirow[t]{4}{*}{ SRR } & 1000 & $9.1 \mathrm{E}-01$ & $5.2 \mathrm{E}-04$ & 1,500 & 63.4 & 2.7 \\
\hline & 400 & $4.4 \mathrm{E}-01$ & $3.4 \mathrm{E}-04$ & 1,070 & 76.5 & 4.3 \\
\hline & 200 & $2.3 \mathrm{E}-01$ & $3.0 \mathrm{E}-04$ & 760 & 79.2 & 4.8 \\
\hline & 100 & $1.2 \mathrm{E}-01$ & $1.9 \mathrm{E}-04$ & 620 & 87.0 & 7.7 \\
\hline \multirow[t]{5}{*}{ CST } & 5000 & $1.9 \mathrm{E}+00$ & $1.0 \mathrm{E}-03$ & 1,850 & 27.0 & 1 \\
\hline & 1000 & 7.9E-01 & $6.4 \mathrm{E}-04$ & 1,020 & 54.9 & 2 \\
\hline & 400 & $3.9 \mathrm{E}-01$ & $4.5 \mathrm{E}-04$ & 640 & 67.6 & 3 \\
\hline & 200 & $2.2 \mathrm{E}-01$ & $3.2 \mathrm{E}-04$ & 670 & 78.7 & 5 \\
\hline & 100 & $1.3 \mathrm{E}-01$ & $1.3 \mathrm{E}-04$ & 840 & 91.2 & 11 \\
\hline \multirow[t]{5}{*}{$\mathrm{KCoCF}$ (gr) } & 5000 & $5.9 \mathrm{E}+00$ & $1.1 \mathrm{E}-04$ & 51,800 & 92.0 & 13 \\
\hline & 2000 & $2.8 \mathrm{E}+00$ & $3.6 \mathrm{E}-05$ & 68,400 & 98.6 & 42 \\
\hline & 1000 & $1.4 \mathrm{E}+00$ & $2.1 \mathrm{E}-05$ & 59,700 & 98.5 & 67 \\
\hline & 400 & $5.7 \mathrm{E}-01$ & $8.6 \mathrm{E}-05$ & 58,400 & 99.3 & 143 \\
\hline & 200 & $2.8 \mathrm{E}-01$ & 7.1E-06 & 36,900 & 99.5 & 200 \\
\hline
\end{tabular}

${ }^{2}$ Conditions of batch equilibration tests: $10 \mathrm{~mL}$ supernate; $100,50,25,10,5$, or $2 \mathrm{mg}$ sorbent; 224 -mixing time at room temperature; initial $\mathrm{pH}$ of supernate $=12.6$. The $\mathrm{Na}, \mathrm{K}$, and $\mathrm{Cs}$ concentrations in the supernate were $3.97,0.36$, and $1.4 \times 10^{-6} M$, respectively.

${ }^{\text {bSRR }}=$ resorcinol/formaldehyde ion-exchange resin $(425$ to $595 \mu \mathrm{m})$; CST = crystalline silicotitanate (fine powder).; $\mathrm{KCoCF}(\mathrm{gr})=$ granular potassium cobalt hexacyanoferrate $(210$ to $595 \mu \mathrm{m})$.

${ }^{\circ} \mathrm{S} / \mathrm{E}=$ ratio of supernate $(\mathrm{mL})$ to mass of sorbent $(\mathrm{g})$. 


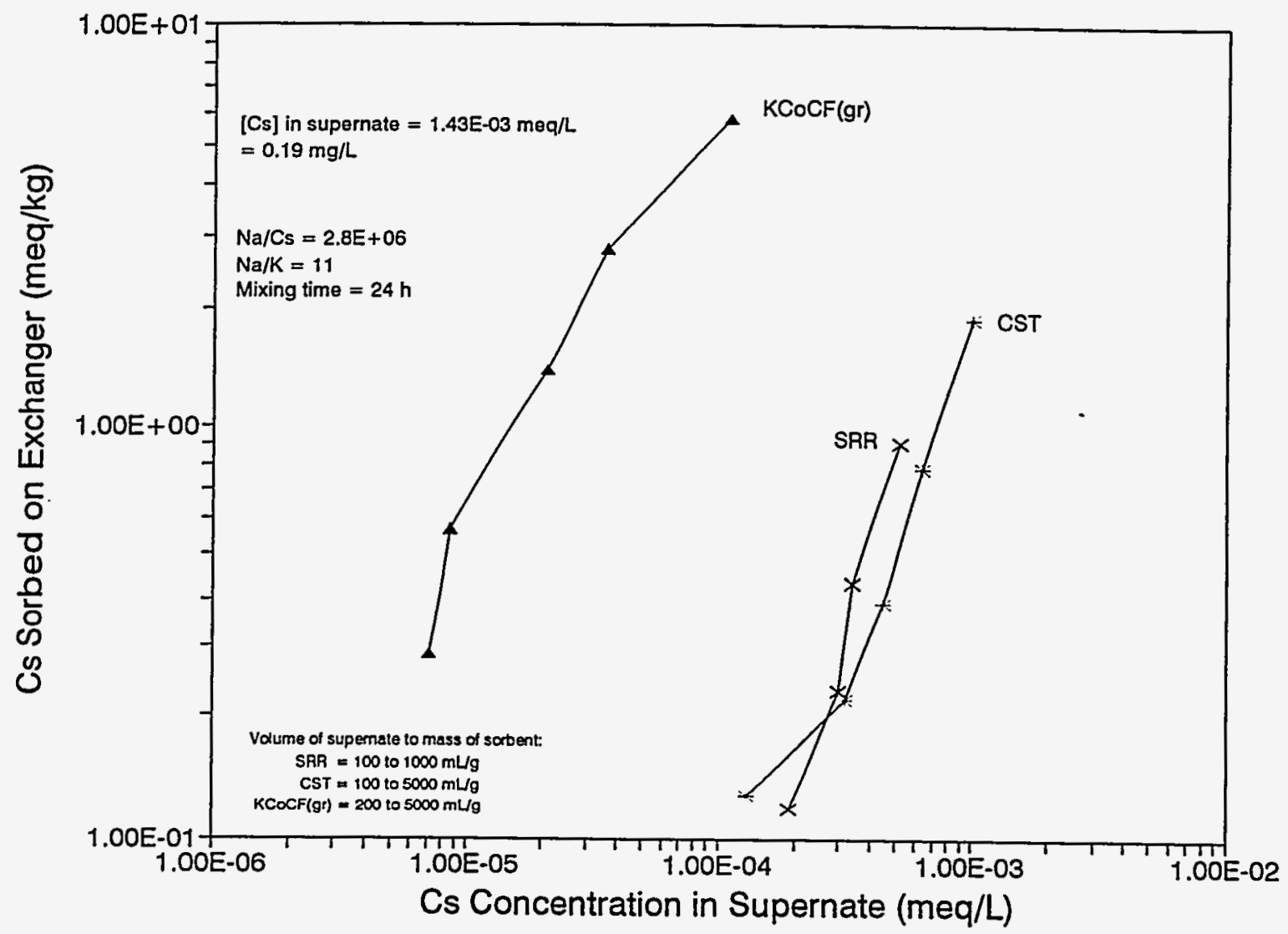

Fig. 2. Cesium sorption isotherms using MVST W-25 supernate. 
Table 8. Effect of varying the cesium concentration of MVST W-25 supernate on the sorption of cesium on the sorbents ${ }^{2}$

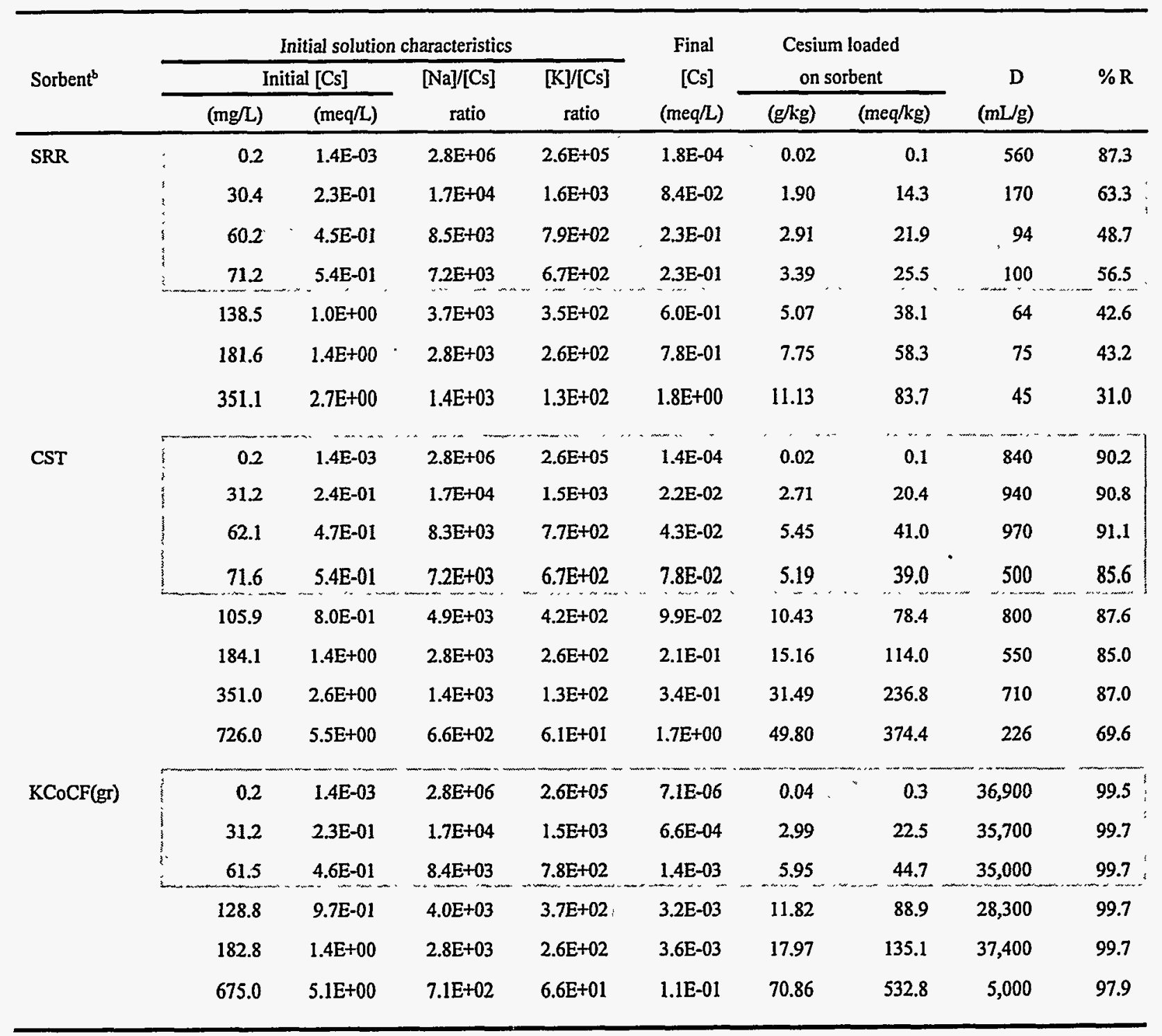

${ }^{8}$ Conditions of batch equilibration tests: $5 \mathrm{~mL}$ supernate $/ 50 \mathrm{mg}$ sorbent; $\geq 24-\mathrm{h}$ mixing time at room temperature; initial $\mathrm{pH}$ of supernate $=12.6$. The cesium concentration of the supernate was varied by adding predetermined amounts of $0.0752 \mathrm{M}$ nonradioactive $\mathrm{CsCl}$ stock solution. The initial [Cs] in the supernate was $0.19 \mathrm{mg} / \mathrm{L}$. The shaded areas of the table represent Hanford-type supernate tests; the cesium concentrations in the supernates of the 17 Hanford tanks were $\leq 86 \mathrm{mg} / \mathrm{L}$ (see Sect. 2).

bSRR = resorcinol/formaldehyde ion-exchange resin (425 to $595 \mu \mathrm{m}) ; \mathrm{CST}=$ crystalline silicotitanate (fine powder); $\mathrm{KCoCF}(\mathrm{gr})=$ granular potassium cobalt hexacyanoferrate $(210$ to $595 \mu \mathrm{m})$. 


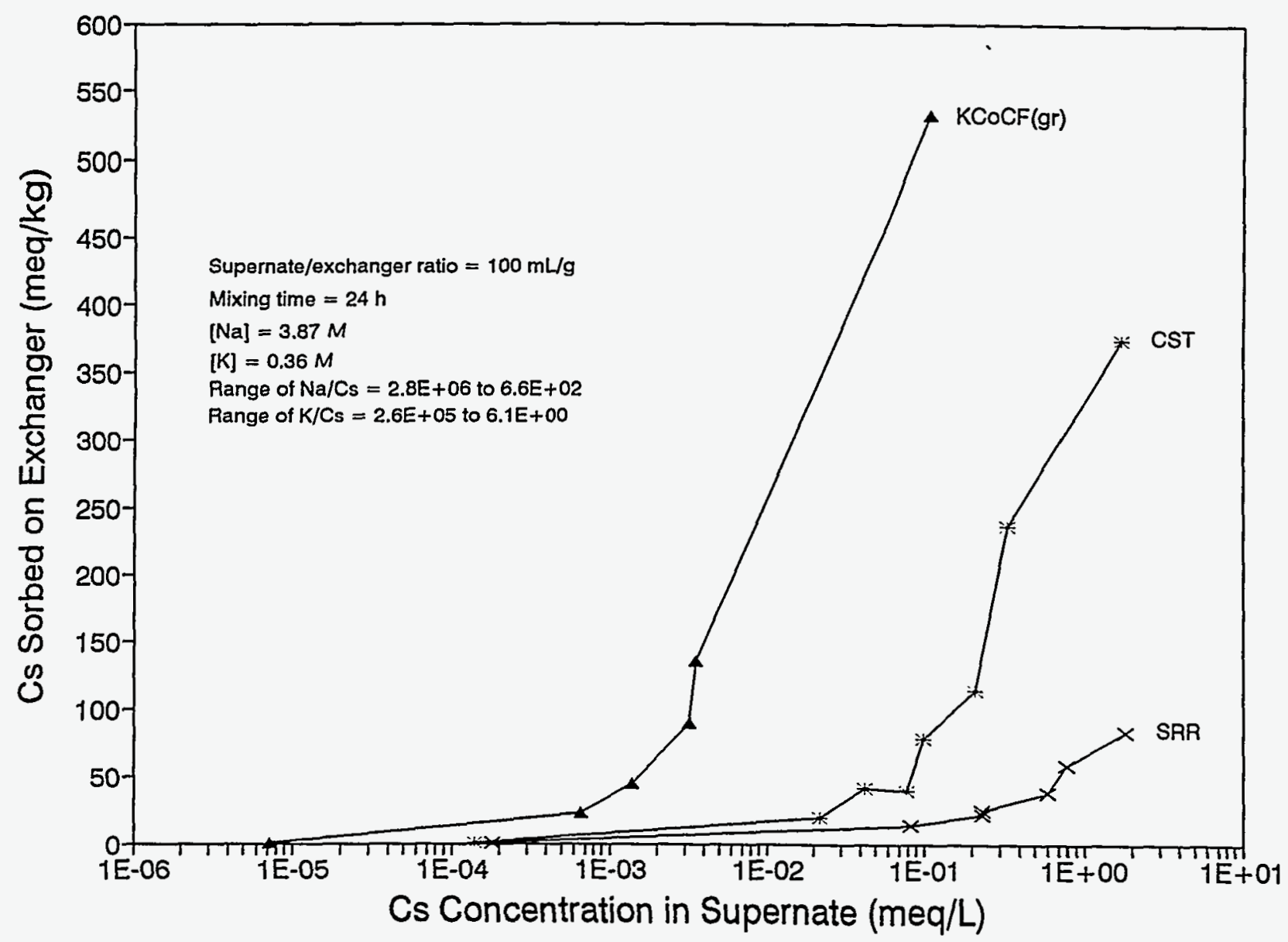

Fig. 3. Cesium sorbed on exchangers vs cesium remaining in supernate. 


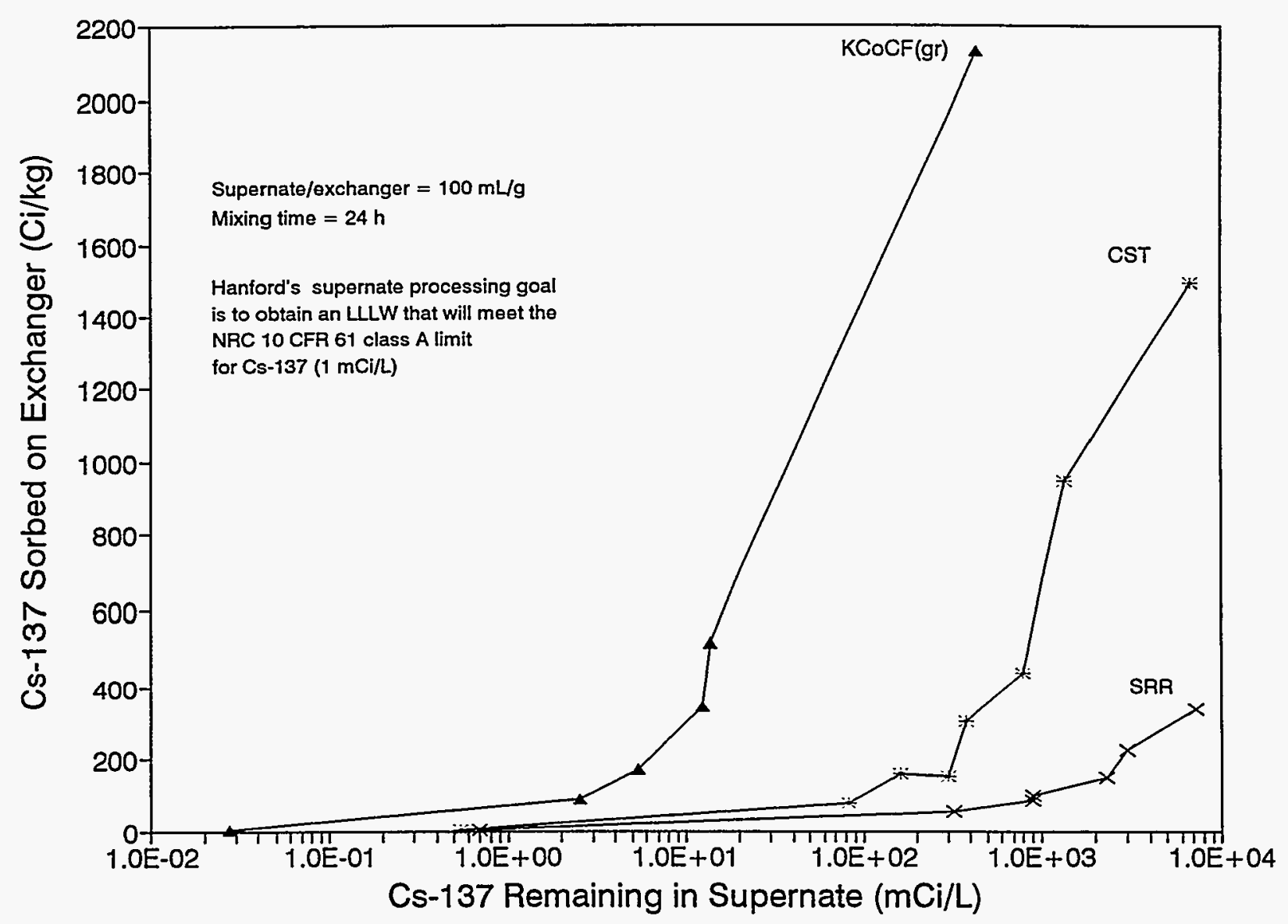

Fig. 4. Cesium-137 sorbed on exchangers vs that remaining in supernate. 


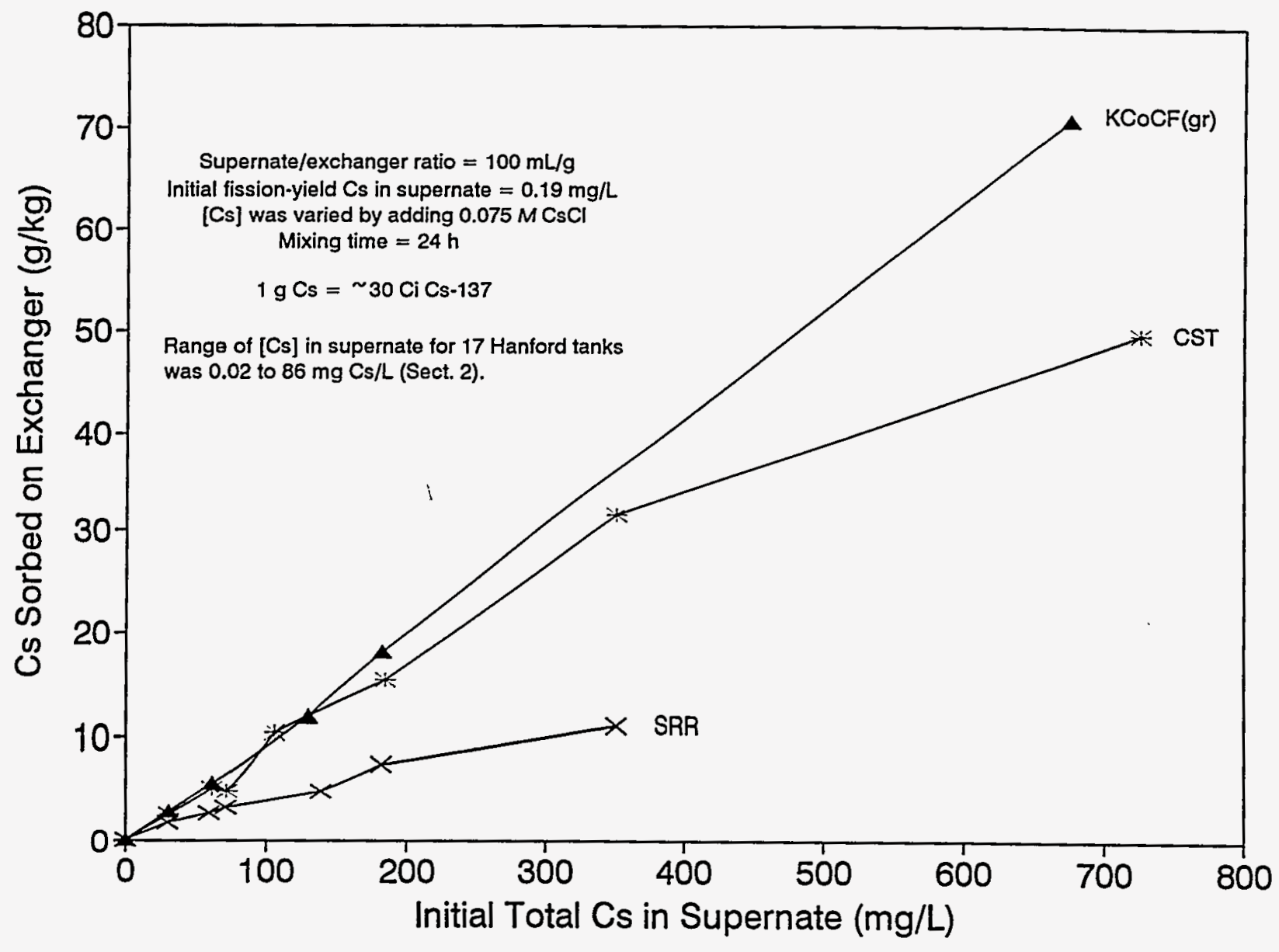

Fig. 5. Cesium sorbed on exchangers vs initial cesium concentration in supernate. 


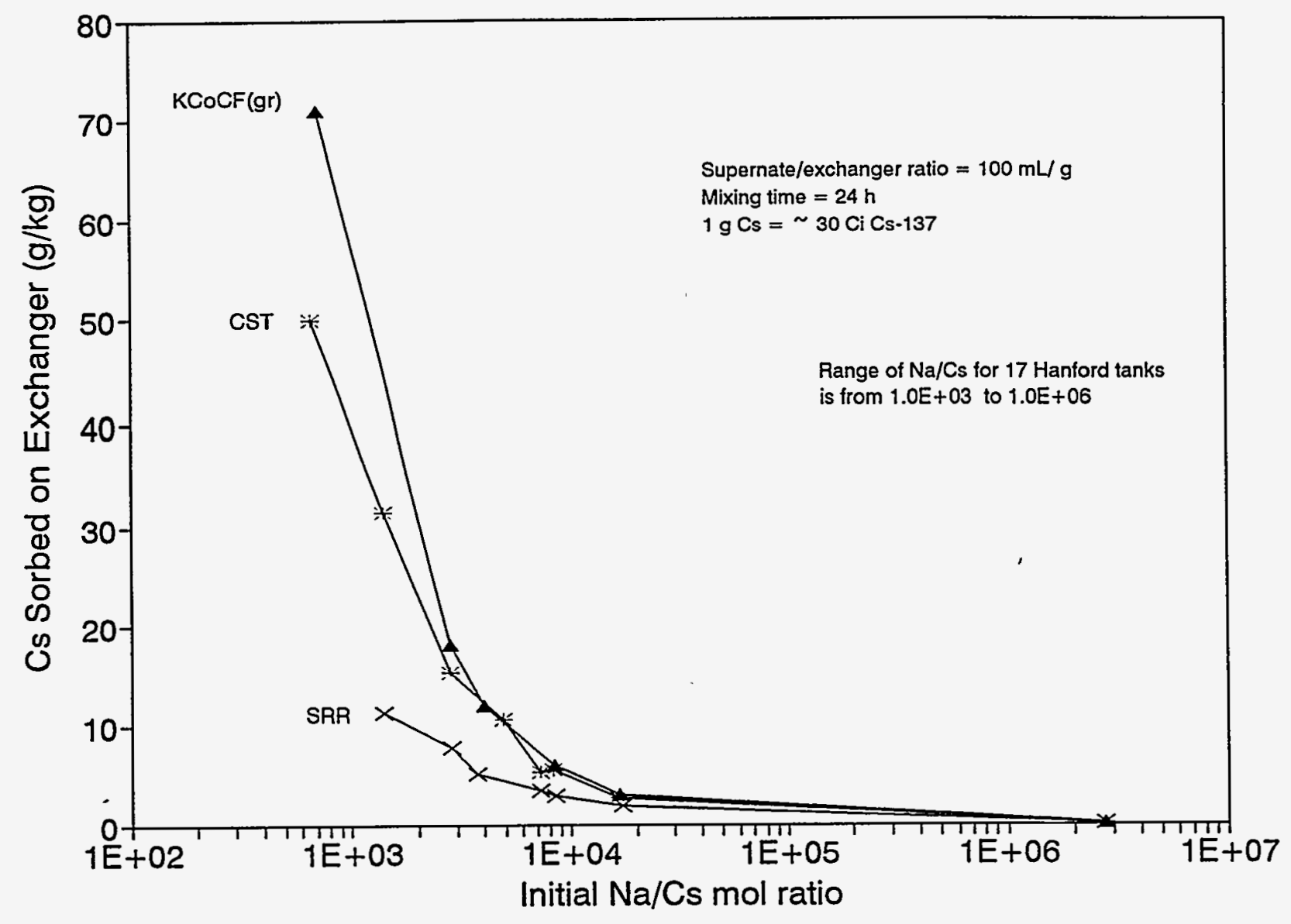

Fig. 6. Cesium sorbed on exchangers vs initial $\mathrm{Na} / \mathrm{Cs} \mathrm{mol}$ ratio. 


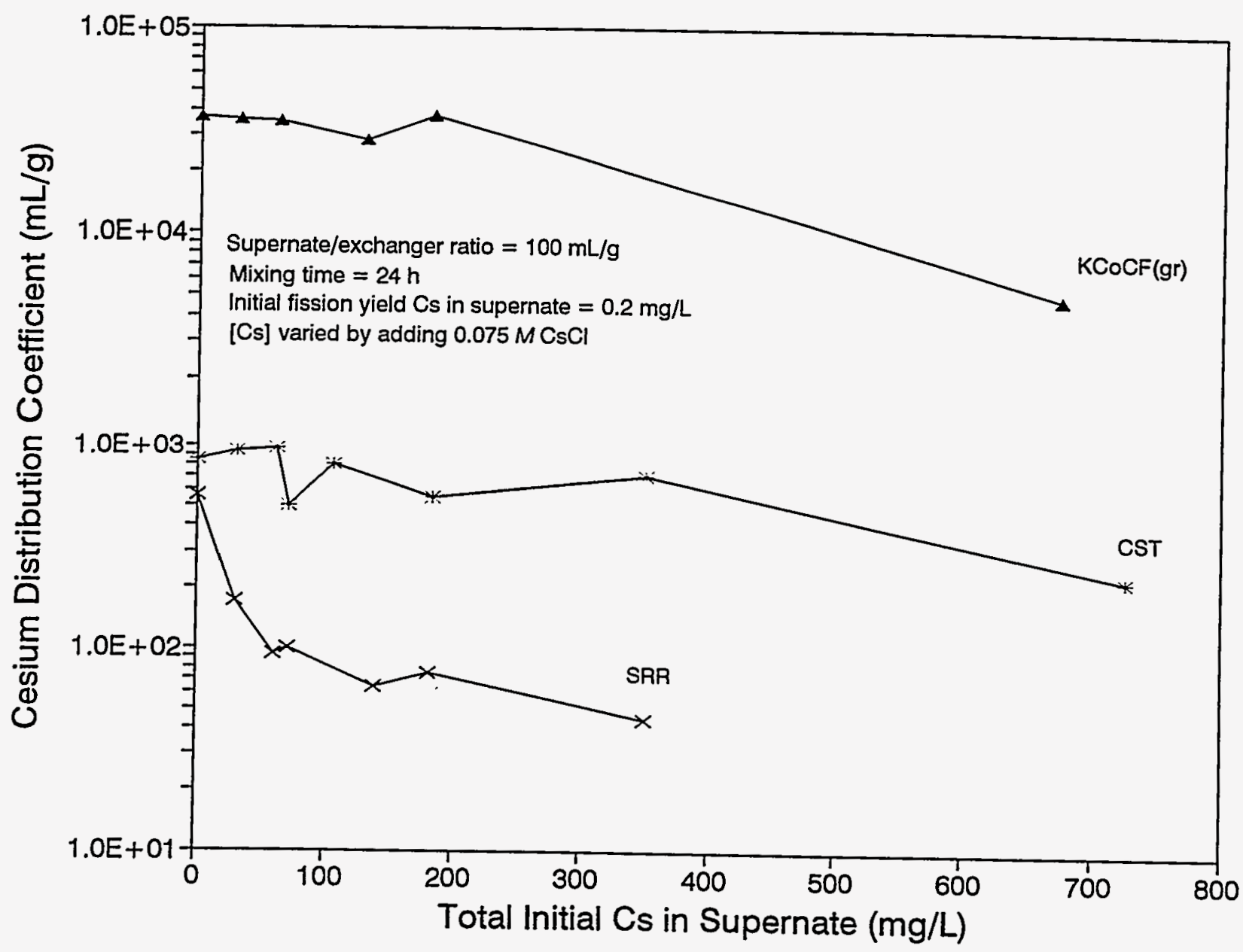

Fig. 7. Effect of cesium concentration on the cesium distribution coefficient. 
to 87 for SRR, 70 to 91 for CST, and 98 to 99.7 for $\mathrm{KCoCF}$ (gr). The $\mathrm{D}$ and $\% \mathrm{R}$ values were fairly constant for supernate samples with Cs concentrations up to $351 \mathrm{mg} / \mathrm{L}$ for CST and up to $183 \mathrm{mg} / \mathrm{L}$ for $\mathrm{KCoCF}$ (gr); this was also the case for SRR in the batch tests conducted with supernates with cesium concentrations in the range of 30.4 to $181.6 \mathrm{mg} / \mathrm{L}$. The $\mathrm{D}$ and $\% \mathrm{R}$ values for the SRR batch test with $0.19-\mathrm{mg} \mathrm{Cs} / \mathrm{L}$ supernate samples were much higher than those obtained in the other SRR batch tests.

In Fig. 3, the amounts of cesium sorbed on the exchangers (meq $/ \mathrm{kg}$ ) are plotted as a function of the concentrations of cesium remaining in the supernate (meq/L). These data are also given in Table 7 . The cesium loading effectiveness was of the order $\mathrm{KCoCF}(\mathrm{gr})>\mathrm{CST}>\mathrm{SRR}$. The sorption results for the supernate samples with initial cesium concentrations of $\sim 183 \mathrm{mg} / \mathrm{L}$ provide an equitable comparison of the exchangers. About $58 \mathrm{meq} / \mathrm{kg}(7.8 \mathrm{~g} / \mathrm{kg}), 114 \mathrm{meq} / \mathrm{kg}(15.2 \mathrm{~g} / \mathrm{kg})$, and $135 \mathrm{meq} / \mathrm{kg}(18.0 \mathrm{~g} / \mathrm{kg})$ of cesium were loaded on SRR, CST, and KCoCF(gr), respectively. Given the same order, the amounts of cesium remaining in the supernate were $0.78 \mathrm{meq} / \mathrm{L}(104 \mathrm{mg} / \mathrm{L}), 0.21 \mathrm{meq} / \mathrm{L}(28 \mathrm{mg} / \mathrm{L})$, and $0.004 \mathrm{meq} / \mathrm{L}$ $(0.5 \mathrm{mg} / \mathrm{L})$.

One of Hanford's goals with regard to processing supernate is to obtain an LLLW that will meet the NRC 10 CFR 61 class A limit for ${ }^{137} \mathrm{Cs}$ of $1 \mathrm{mCi} / \mathrm{L}\left(0.0115 \mathrm{mg} / \mathrm{L}{ }^{137} \mathrm{Cs}\right)$. This limit equates to a total cesium concentration of $0.034 \mathrm{mg} / \mathrm{L}$, or $2.6 \times 10^{-4} \mathrm{meq} / \mathrm{L}$. Under the conditions of our experiments, $\mathrm{KCoCF}(\mathrm{gr})$ was the most efficient sorbent for cesium. A greater mass of sorbent per unit volume is required with the CST and SRR to accomplish the same decontamination. For example, current batch tests $(50 \mathrm{mg}$ absorbent $/ 5 \mathrm{~mL}$ of supernate) show that $\mathrm{KCoCF}$ (gr) reduces the cesium to the required degree for a Hanford supernate simulant, whereas CST and SRR resin do not. In batch tests using KCoCF(gr) where the initial cesium concentrations of the supernate were $0.2,31.2$, and $61.5 \mathrm{mg} / \mathrm{L}$, which covers a good portion of the range of cesium concentration in the 17 Hanford tanks, the final cesium concentrations were $7.1 \times 10^{-6}, 6.6 \times 10^{-4}$, and $1.4 \times 10^{-3} \mathrm{meq} / \mathrm{L}$, respectively. If the cold cesium that was added to the MVST W-25 supernate samples had been fission product material, the ${ }^{137} \mathrm{Cs}$ concentrations given in the same order would have been 0.03 , 1.5 , and $5 \mathrm{mCi} / \mathrm{L}$. In similarly conducted tests the values for CST would have been $0.5,85$, and $166 \mathrm{mCi} / \mathrm{L}$, and for SRR would have been $0.7,324$, and $887 \mathrm{mCi} / \mathrm{L}$. In Fig. $4,{ }^{137} \mathrm{Cs}$ sorbed on the exchangers (Ci/kg) was plotted vs the ${ }^{137} \mathrm{Cs}$ remaining in the supernate $(\mathrm{mCi} / \mathrm{L})$. The cold $\mathrm{Cs}$ was calculated as fission-derived Cs; $1 \mathrm{meq}$ Cs was equal to $3857 \mathrm{mCi}{ }^{137} \mathrm{Cs}$. The specific activity of ${ }^{137} \mathrm{Cs}$ is $87 \mathrm{mCi} / \mathrm{mg}$. If the assumption is made that one-third of the total mass of Cs was ${ }^{137} \mathrm{Cs}$, then the maximum ${ }^{137} \mathrm{Cs}$ sorbed was $2100 \mathrm{Ci} / \mathrm{kg}$ for $\mathrm{KCoCF}$ (gr), $1400 \mathrm{Ci} / \mathrm{kg}$ for CST, and $323 \mathrm{Ci} / \mathrm{kg}$ for SRR. In batch tests where the Cs concentrations in the supernate samples were $60.2 \mathrm{mg} / \mathrm{L}$, which would represent a high concentration of $\mathrm{Cs}$ for Hanford 
supernates, the hypothetical ${ }^{137} \mathrm{Cs}$ sorbed was $172 \mathrm{Ci} / \mathrm{kg}$ for $\mathrm{KCoCF}(\mathrm{gr}), 158 \mathrm{Ci} / \mathrm{kg}$ for CST, and $84 \mathrm{Ci} / \mathrm{kg}$ for SRR.

Plots of cesium sorbed on the exchangers vs the initial concentrations of cesium in the samples of supernate are given in Fig. 5. The slopes were different for each exchanger, and maximum loading of cesium on the sorbents was not achieved for the feed concentrations employed in the batch tests with any of the sorbents.

Plots of cesium sorbed on the exchangers versus the initial $\mathrm{Na} / \mathrm{Cs}$ mol ratios of the supernate samples are shown in Fig. 6. For comparison, the range of $\mathrm{Na} / \mathrm{Cs}$ mol ratios for the Hanford supernates was $1.0 \times 10^{3}$ to $1.0 \times 10^{6}$; however, a major difference is that the $\mathrm{Na}$ concentrations of some of the Hanford supernates are much higher than those of the MVST W-25 supernate samples (see Sect. 1). The Na concentration of the MVST W-25 supernate samples was $\leq 3.87 \mathrm{M}$. Seven of the 17 Hanford tanks have Na concentrations between 6.4 and $14.6 \mathrm{M}$; the other ten tanks have Na concentrations that are $s 4 M$. On the other hand, only three Hanford tank supernates have potassium concentrations greater than the $0.36 \mathrm{M}$ of the MVST W-25 supernate; those had concentrations of $0.39,0.86$, and $1.07 \mathrm{M}$. Table 8 shows that varying the $\mathrm{Na} / \mathrm{Cs}$ and the $\mathrm{K} / \mathrm{Cs}$ mol ratios from $2.8 \times 10^{6}$ to $2.8 \times 10^{3}$ and $2.6 \times 10^{5}$ to $2.6 \times 10^{2}$, respectively, caused little effect on the cesium $\mathrm{D}$ and \% $\mathrm{R}$ values using $\mathrm{KCOCF}(\mathrm{gr})$ and $\mathrm{CST}$. The $\mathrm{D}$ and $\% \mathrm{R}$ values for $\mathrm{SRR}$ decreased significantly when the concentration of cesium in the supernate was increased from 0.2 to $30.3 \mathrm{mg} / \mathrm{L}$. For the supernate samples with a $\mathrm{Na} / \mathrm{Cs}$ mol ratio of $2.8 \times 10^{3}$ and a K/Cs mol ratio of $2.6 \times 10^{2}$, the $\mathrm{D}$ and $\% \mathrm{R}$ values for SRR were only $75 \mathrm{~mL} / \mathrm{g}$ and 43 , respectively. For the $\mathrm{Na} / \mathrm{Cs}$ and $\mathrm{K} / \mathrm{Cs}$ mol ratios stated above, the $\mathrm{D}$ decreased by $87 \%$ for SRR, and very little for $\mathrm{KCoCF}(\mathrm{gr})$ or CST.

\subsubsection{Effect of $K$ and Cs Concentrations on Removing Cs from MVST W-25 Supernate with Sorbents}

Batch tests were also conducted in which both the $\mathrm{K}$ and Cs concentrations of samples of MVST W-25 supernate were adjusted with predetermined amounts of $4.25 \mathrm{M} \mathrm{KCl}$ and $0.075 \mathrm{MCsCl}$ stock solutions. In each equilibration test, $-5 \mathrm{~mL}$ of adjusted supernate was mixed with $\sim 50 \mathrm{mg}$ of sorbent at room temperature. The pretest characteristics and cesium loading results are provided in Table 9. In the first row for each sorbent in Table 9, the Cs loading results for nonaltered supernate samples are provided for comparison. In the second row for each sorbent, only the cesium concentration of the supernate was increased. In the second and third unshaded rows, only the potassium concentrations were increased. In the second and third shaded rows, both the potassium and cesium concentrations were increased. Three different concentrations of potassium $(0.36,0.77$, and $1.02 M)$ were tested at high and nonadjusted cesium concentrations. The $\mathrm{Na} / \mathrm{K}$ 
Table 9. Effect of $K$ and $C s$ concentrations on removing $C s$ from MVST W-25 supernate with sorbents ${ }^{2}$

\begin{tabular}{|c|c|c|c|c|c|c|c|c|c|}
\hline \multirow{3}{*}{ Sorbent ${ }^{b}$} & \multicolumn{6}{|c|}{ Pretest solution characteristics } & \multirow{3}{*}{$\begin{array}{c}D \\
(\mathrm{~mL} / \mathrm{g})\end{array}$} & \multirow{3}{*}{$\% \mathrm{R}$} & \multirow{3}{*}{$\begin{array}{r}\text { Final } \\
{[\mathrm{Cs}]} \\
(M)\end{array}$} \\
\hline & {$[\mathrm{Na}]$} & {$[\mathrm{K}]$} & {$[\mathrm{Cs}]$} & {$[\mathrm{Na}] /[\mathrm{K}]$} & {$[\mathrm{Na}] /[\mathrm{Cs}]$} & {$[\mathrm{K}] /[\mathrm{Cs}]$} & & & \\
\hline & $(M)$ & $(M)$ & $(M)$ & ratio & ratio & ratio & & & \\
\hline \multirow[t]{6}{*}{ SRR } & 3.87 & 0.36 & $1.4 \mathrm{E}-06$ & 10.8 & $2.8 E+06$ & $2.6 \mathrm{E}+05$ & 560 & 87.3 & $1,8 \mathrm{E}-07$ \\
\hline & 3.85 & 0.36 & 5.4E-04 & 10.7 & $7.2 \mathrm{E}+03$ & $6.7 \mathrm{E}+02$ & 100 & 56.5 & $2.4 \mathrm{E}-04$ \\
\hline & 3.46 & 0.77 & $1.3 \mathrm{E}-06$ & 4.5 & $2.7 \mathrm{E}+06$ & $5.9 E+05$ & 290 & 73.7 & $3.4 \mathrm{E}-07$ \\
\hline & 3.49 & 0.71 & $6.9 \mathrm{E}-04$ & 4.9 & $5.1 E+03$ & $1.0 \mathrm{E}+03$ & 74 & 40.2 & $4.1 \mathrm{E}-04$ \\
\hline & 3.22 & 1.03 & $1.3 \mathrm{E}-06$ & 3.1 & $2.5 E+06$ & $7.9 \mathrm{E}+05$ & 250 & 67.8 & $4.2 \mathrm{E}-07$ \\
\hline & 3.18 & 1.02 & $6.4 \mathrm{E}-04$ & 3.1 & $5.0 \mathrm{E}+03$ & $1.6 \mathrm{E}+03$ & 78 & 40.2 & $3.9 \mathrm{E}-04$ \\
\hline \multirow[t]{6}{*}{ CST } & 3.87 & 0.36 & $1.4 \mathrm{E}-06$ & 10.8 & $2.8 E+06$ & $2.6 \mathrm{E}+03$ & 840 & 90.2 & $1.4 \mathrm{E}-07$ \\
\hline & 3.83 & 0.36 & $8.0 \mathrm{E}-04$ & 10.7 & $4.8 \mathrm{E}+03$ & $4.5 \mathrm{E}+02$ & 800 & 87.6 & $9.9 \mathrm{E}-05$ \\
\hline & 3.46 & 0.77 & $1.3 \mathrm{E}-06$ & 4.5 & 2.7E+06 & $5.9 \mathrm{E}+05$ & 820 & 88.8 & $1.5 \mathrm{E}-07$ \\
\hline & 3.48 & 0.72 & $7.0 \mathrm{E}-04$ & 4.8 & $5.0 \mathrm{E}+03$ & $1.0 \mathrm{E}+03$ & 880 & 89.1 & $7.6 \mathrm{E}-05$ \\
\hline & 3.22 & 1.03 & $1.3 \mathrm{E}-06$ & 3.1 & $2.5 E+06$ & $7.9 \mathrm{E}+05$ & 690 & 88.0 & $1.6 \mathrm{E}-07$ \\
\hline & 3.18 & 1.03 & $6.4 \mathrm{E}-04$ & 3.1 & $5.0 \mathrm{E}+03$ & $1.6 \mathrm{E}+03$ & 800 & 87.2 & $8.2 \mathrm{E}-05$ \\
\hline \multirow[t]{6}{*}{$\mathrm{KCoCF}(\mathrm{gr})$} & 3.87 & 0.36 & $1.4 \mathrm{E}-06$ & 10.8 & $2.8 \mathrm{E}+06$ & $2.6 \mathrm{E}+05$ & 36,900 & 99.5 & $7.0 \mathrm{E}-09$ \\
\hline & 3.82 & 0.36 & $4.6 \mathrm{E}-04$ & 10.6 & $8.3 E+03$ & $7.8 \mathrm{E}+02$ & 35,000 & 99.7 & $1.9 \mathrm{E}-06$ \\
\hline & 3.48 & 0.77 & $1.3 \mathrm{E}-06$ & 4.5 & $2.7 \mathrm{E}+06$ & $5.9 \mathrm{E}+05$ & 6,660 & 98.4 & $2.1 \mathrm{E}-08$ \\
\hline & 3.47 & 0.72 & $7.2 \mathrm{E}-04$ & 4.8 & $4.8 E+03$ & $1.0 \mathrm{E}+03$ & 8,970 & 99.0 & $7.2 \mathrm{E}-06$ \\
\hline & 3.21 & 1.02 & 1.3E-06 & 3.1 & $2.5 E \div 06$ & $7.8 \mathrm{E}+05$ & 6,420 & 98.2 & 2.3E-08 \\
\hline & 3.18 & 1.02 & $6.4 \mathrm{E}-04$ & 3.1 & $5.0 \mathrm{E}+03$ & $1.6 \mathrm{E}+03$ & 13,125 & 99.1 & $5.8 \mathrm{E}-06$ \\
\hline
\end{tabular}

${ }^{2}$ Conditions of batch equilibration tests: $5 \mathrm{~mL}$ supernate/50 mg sorbent; $\geq 24-\mathrm{h}$ mixing time at room temperature; initial $\mathrm{pH}$ of supernate $=12.6$. The $\mathrm{K}$ and $\mathrm{Cs}$ concentrations of the supernate samples were varied by adding predetermined amounts of $4.25 \mathrm{M} \mathrm{KCl}$ and $0.075 \mathrm{M} \mathrm{CsCl}$ stock solutions. The concentrations of $\mathrm{Na}, \mathrm{K}$, and $\mathrm{Cs}$ in the supernate as received from tank W-25 were $3.87,0.36$, and $1.4 \times 10^{-6} \mathrm{M}$, respectively.

${ }^{b} \mathrm{SRR}=$ resorcinol/formaldehyde ion-exchange resin $(425$ to $595 \mu \mathrm{m})$. CST = crystalline silicotitanate (fine powder); $\mathrm{KCoCF}(\mathrm{gr})=$ granular potassium cobalt hexacyanoferrate $(210$ to $595 \mu \mathrm{m})$. 
mol ratios ranged from 10.8 to 3.1. The ranges of $\mathrm{Na} / \mathrm{Cs}$ and $\mathrm{K} / \mathrm{Cs} \mathrm{mol}$ ratios were from $5.0 \times 10^{3}$ to $2.8 \times 10^{6}$ and from $4.5 \times 10^{2}$ to $2.6 \times 10^{5}$, respectively. These characteristics are similar to those for the supernates of the 17 Hanford tanks (see Sect. 2), which ranged from $3.7 \times 10^{3}$ to $7.1 \times 10^{7}$ for $\mathrm{Na} / \mathrm{Cs} \mathrm{mol}$ ratios and from $9.1 \times 10^{1}$ to $7.2 \times 10^{5}$ for $\mathrm{K} / \mathrm{Cs} \mathrm{mol}$ ratios.

When the potassium concentrations of samples of MVST W-25 supernate were increased successively from $0.36 M$ to $0.77 M$ and to $1.03 M$ for SRR (see Figs. 8 and 9), the $\mathrm{D}$ and \% $\mathrm{R}$ values decreased from $560 \mathrm{mg} / \mathrm{L}$ to $290 \mathrm{~mL} / \mathrm{g}$ and to $250 \mathrm{~mL} / \mathrm{g}$ and from $87.3 \%$ to $73.7 \%$ to $67.8 \%$, respectively. Increasing the cesium concentration from $1.4 \times 10^{-6}$ to $5.4 \times 10^{-4}$ while keeping the sodium and potassium concentrations constant had a larger effect on the $\mathrm{D}$ and $\% \mathrm{R}$, decreasing them from 560 to $100 \mathrm{~mL} / \mathrm{g}$ and 87.3 to $56.5 \%$, respectively. Increasing the concentration of potassium to $0.71 \mathrm{M}$ caused an additional decrease in the $\mathrm{D}$ and $\% \mathrm{R}$ values to $74 \mathrm{~mL} / \mathrm{g}$ and $40.2 \%$, respectively; however, an additional increase of the $\mathrm{K}$ concentration caused no further change in these values.

The cesium $\mathrm{D}$ and $\% \mathrm{R}$ values for CST were affected to a lesser extent by increases in the potassium and cesium concentrations of the supernate. When only the cesium concentration of the supernate was increased, a slight improvement was noted in the $\mathrm{D}$ and $\% \mathrm{R}$ values for $\mathrm{KCoCF}(\mathrm{gr})$; however, increasing the potassium concentrations to 0.77 and to $1.02 M$ did lower the $\mathrm{D}$ and $\% \mathrm{R}$, but only minimally. For supernates at the higher cesium concentrations, the $\mathrm{D}$ and $\% \mathrm{R}$ values were essentially unaffected by increased potassium concentrations (see Table 9).

In summary, under the conditions of the tests, increasing either the potassium or the cesium concentration of the MVST W-25 supernate resulted in significantly lower cesium $D$ and \% $R$ values for SRR. Increasing the potassium concentration of the supernate slightly decreased the cesium $D$ and $\% R$ values for $\mathrm{KCoCF}(\mathrm{gr}$ ), while increasing the cesium concentration slightly improved the cesium $\mathrm{D}$ and $\% \mathrm{R}$ values. Increasing the potassium and cesium concentrations of the supernate had no effect on the CST. Under all of the conditions of these tests, the effectiveness of removing the cesium from the supernate remained the same: $\mathrm{KCOCF}>\mathrm{CST} \gg \mathrm{SRR}$.

\section{DISCUSSION}

Various ion-exchange materials and adsorbents have been tested for their efficacy in removing cesium from high-salt-concentration radwastes. This report is primarily concerned with the comparative evaluation of four materials: SRR, a resorcinol/formaldehyde ion-exchange resin developed at Savannah River; a 


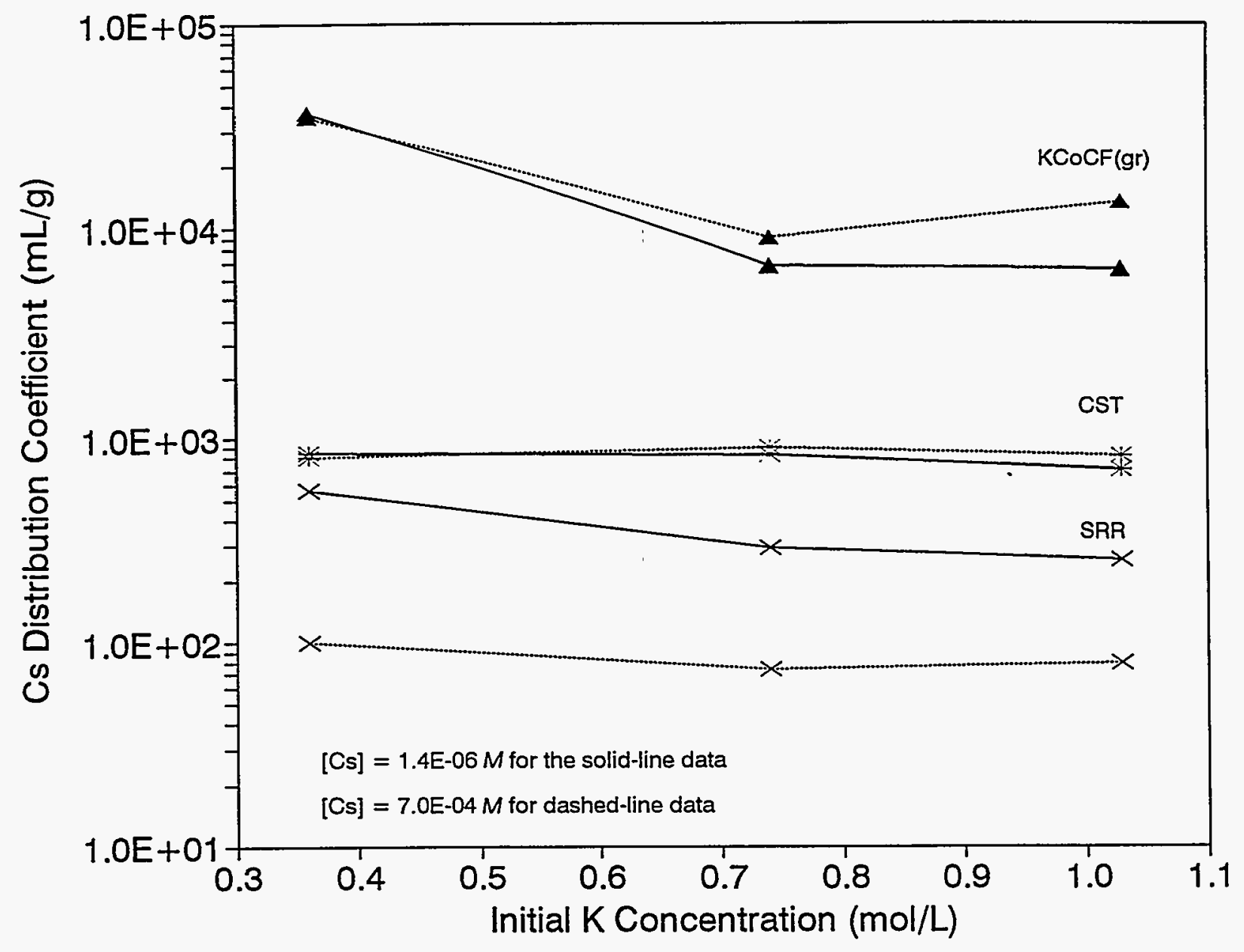

Fig. 8. Effect of potassium concentration on the cesium distribution coefficient. 


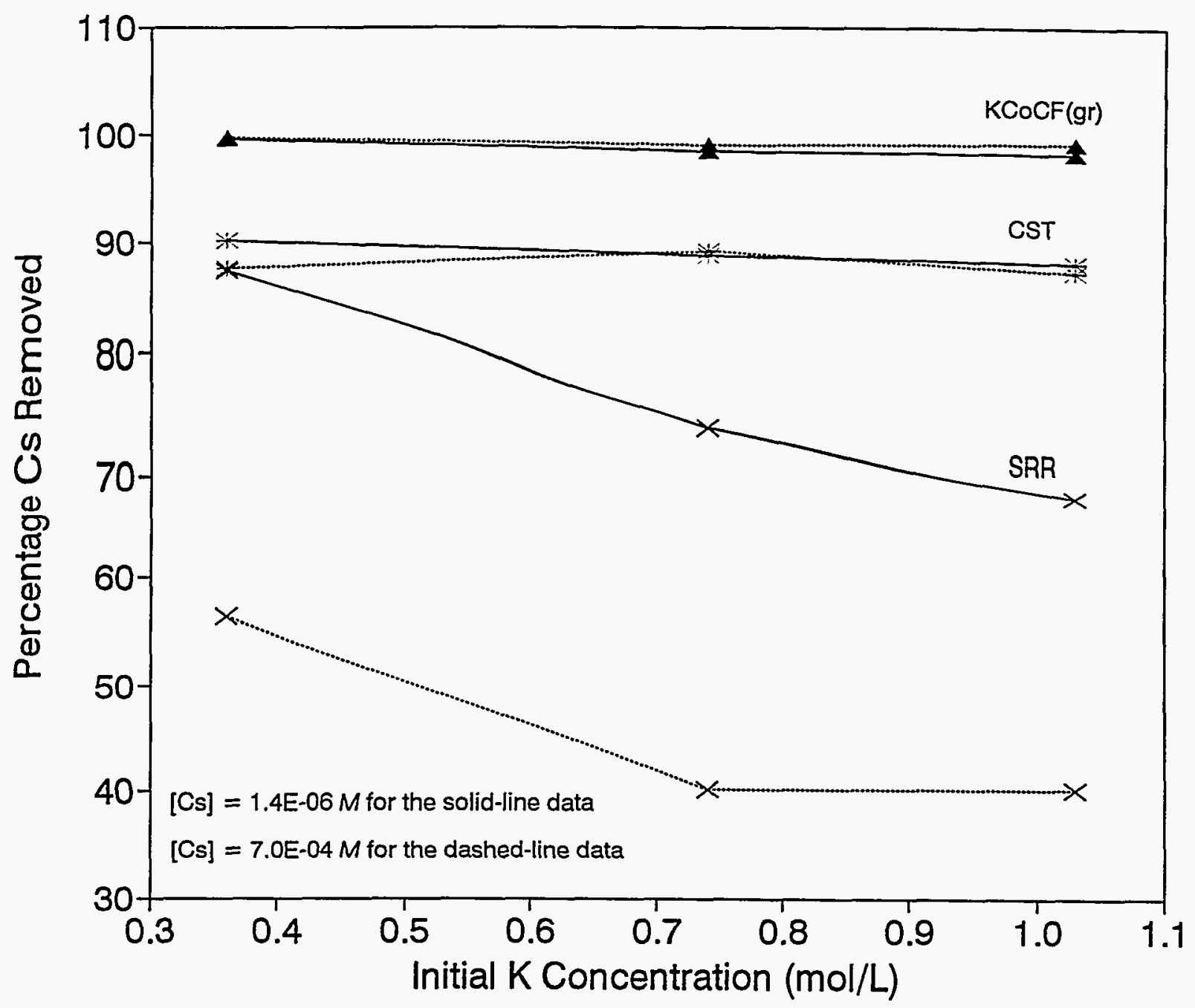

Fig. 9. Effect of potassium concentration on percentage cesium removed from supernate. 
phenolic resin known as Duolite ${ }^{\mathrm{TM}}$ CS-100 manufactured by Rohm and Haas, Inc.; crystalline silicotitanate (CST), an inorganic ion exchanger developed by SNL and Texas A\&M University; and granular potassium cobalt hexacyanoferrate $[\mathrm{KCoCF}(\mathrm{gr})]$, an inorganic exchanger already being employed in plant-scale columnar experiments in Finland. In addition, two types of microspheres-titanium monohydrogen phosphate and hydrous titanium oxide-were produced with occluded $\mathrm{KCOCF}$ and $\mathrm{NaCoCF}$ (approximately $20 \mathrm{wt} \%)$.

\subsection{COMPARATIVE STUDIES ON CESIUM REMOVAL}

All the experiments described in this report were based on batch extraction studies only. Future columnar studies are implicit to the use of these materials in actual plant applications. All materials except the CST exchanger are already available in particle sizes suitable for column studies. Efforts are currently under way to develop CST into an engineered matrix for use in columns. ${ }^{17}$

The data presented here indicate that granular KCoCF is the most effective, and Duolite ${ }^{\mathrm{TM}} \mathrm{CS}-100$ is the least effective, of the exchangers evaluated for removing cesium from the concentration-adjusted MVST W-25 supernates. KCoCF efficiently extracted cesium when prepared as a stable granular particle or when occluded in titanium monohydrogen phosphate or hydrous titanium oxide microspheres. However, it was noted that the microspheres containing cobalt hexacyanoferrate showed somewhat slower uptake of cesium than the granular $\mathrm{KCoCF}$, requiring 2 to $24 \mathrm{~h}$ as opposed to $\sim 0.25 \mathrm{~h}$ for near-maximum removal. (The literature ${ }^{21}$ indicates equilibrium with the granular $\mathrm{KCoCF}$ is achieved in about $1 \mathrm{~h}$.)

All exchanger materials were obtained either commercially or from private sources with the exception of those containing KCoCF. The latter were synthesized at ORNL by a modification of the procedure reported by Prout et al..$^{20,21}$ (see also Appendix B). While the $\mathrm{Co} / \mathrm{Fe}$ mol ratio was 1.4 in our procedure, which is that given in the literature, the $\mathrm{K} / \mathrm{Co} / \mathrm{Fe}$ elemental ratio of $1.2 / 1.3 / 1.0$ differed somewhat from that reported by Prout et al. ${ }^{20}$ (i.e.,1.6/1.4/1.0). Our modified preparation procedure is designed to yield product without contamination by sodium (which would have the potential for occlusion in the structure of the final product).

The inclusion of the cobalt hexacyanoferrate within a microsphere matrix was designed to test a potentially more useful composite inorganic ion exchanger which, when loaded, could be washed to remove excess salts and then dried to yield a waste form that could be stored directly, vitrified in glass, or added to grout. Granular KCoCF adsorbs cesium effectively over a wide $\mathrm{pH}$ range ( 0 to 12.5 ), especially at the extremes of the range. 
The cesium adsorption data for SRR, CST, and $\mathrm{KCoCF}(\mathrm{gr})$ were fitted to a form of the Freundlich isotherm shown in Eq. (1) for initial cesium concentrations $<352 \mathrm{mg} / \mathrm{L}$ :

$$
\ln \left(\mathrm{Cs}_{\mathrm{ads}}\right)=a \ln \left(\mathrm{Cs}_{\mathrm{eq}}\right)+B
$$

Here $\mathrm{Cs}_{\mathrm{ads}}$ is the amount of solute adsorbed per unit weight of the adsorbent $(\mathrm{mmol} / \mathrm{g})$ and $\mathrm{Cs}_{\mathrm{eq}}$ is the equilibrium concentration of the solute remaining in the solution phase $(\mathrm{mmol} / \mathrm{L})$. The regressed coefficients, shown in Table 10, fitted the adsorption data reasonably well as indicated by correlation

Table 10. Regressed coefficients for the fitting of data to the Freundlich Isotherm Model for three adsorbents

\begin{tabular}{|c|c|c|c|}
\hline \multirow[t]{2}{*}{ Adsorbent } & \multicolumn{2}{|c|}{ Freundlich parameters } & \multirow[t]{2}{*}{ Correlation coefficient } \\
\hline & $a$ & $B$ & \\
\hline SRR & $0.693 \pm 0.021$ & 2.13 & 0.996 \\
\hline CST & $0.926 \pm 0.038$ & 4.37 & 0.992 \\
\hline $\mathrm{KCoCF}$ & $0.957 \pm 0.026$ & 8.11 & 0.998 \\
\hline
\end{tabular}

coefficients in excess of 0.99 for the three materials. The regression plots for the sorption data are shown in Fig. 10. The regressed fit deteriorated significantly when the highest initial concentrations of Cs (726 and $675 \mathrm{mg} / \mathrm{L}$ ) were included in the data. It should be emphasized that the parameters listed in Table 10 represent data from only a single supernate, MVST W-25, and should not be applied to other supernates without testing since their ionic contents and $\mathrm{pH}$ levels may differ dramatically.

Industrial, pilot-plant-scale tests have been performed at the Loviisa Nuclear Power Station in Helsinki, Finland, with a granular form of $\mathrm{KCoCF}$ (see Appendix A). This material reportedly had the composition $\mathrm{K}_{1,76} \mathrm{Co}_{1,12} \mathrm{Fe}(\mathrm{CN})_{6}$ and had been prepared using a $\mathrm{Co} / \mathrm{Fe}$ ratio of 1.4. Our product obtained using the same $\mathrm{Co} / \mathrm{Fe}$ ratio had the nominal composition $\mathrm{K}_{1.2} \mathrm{Co}_{1.3} \mathrm{Fe}(\mathrm{CN})_{6}$, which, because of its lower $\mathrm{K}$ and higher Co contents, should have a lower exchange capacity for Cs. However, this may not be stated categorically since 


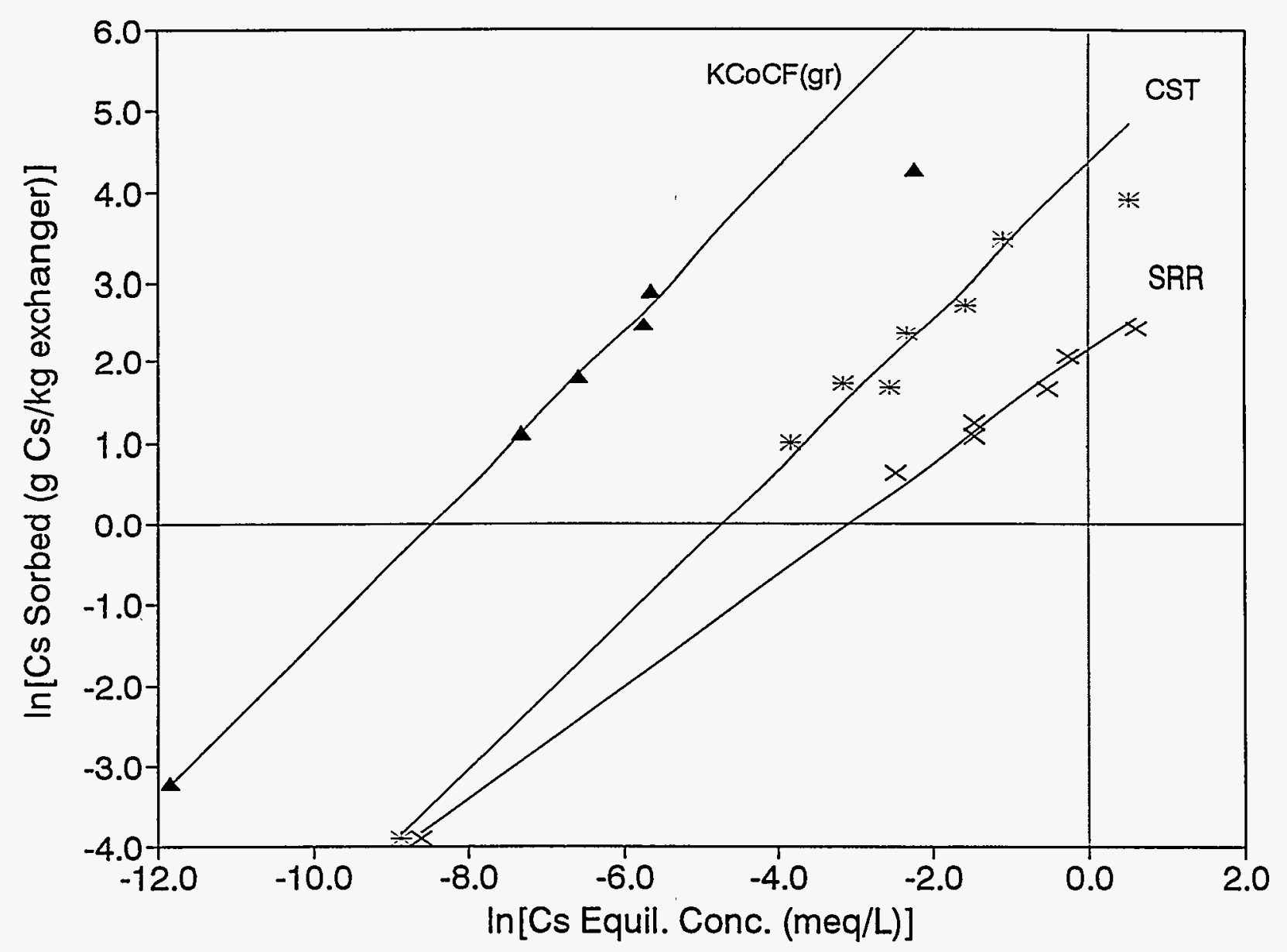

Fig. 10. Freundlich isotherms for ion exchangers evaluated in this study. 
the extent of the exchange reaction may also be related to particulate surface area in some complex fashion. The initial total cesium concentration in the Loviisa supernate was estimated to be about $0.36 \mu \mathrm{g} / \mathrm{L}$, while our studies with the MVST W-25 supernate employed a range of 0.2 to $675 \mathrm{mg} / \mathrm{L}$. Both the $\mathrm{Na}$ and the $\mathrm{K}$ concentrations were higher in the MVST W-25 supernate (3.9 vs $2.6 M \mathrm{Na}$ and 0.36 vs $0.26 M \mathrm{~K}$ ), respectively. Another substantial difference was noted between the two supernates, namely the high boron concentration (5.6 M) of the Loviisa supernate as compared with only a trace of boron in the MVST W-25 supernate. The effect of boron on the uptake of $\mathrm{Cs}$ by $\mathrm{KCOCF}$ is unknown but should be minimal in an ionexchange type of reaction. The effective column loading of granular $\mathrm{KCoCF}$ by cesium at $1 \%$ breakthrough for the Loviisa pilot plant studies was $<16 \mathrm{mg} / \mathrm{kg}$. At our lowest concentration of cesium, which was approximately 500 -fold higher than that at Loviisa, our batch studies yielded a loading of $40 \mathrm{mg} / \mathrm{kg}$. Our studies indicated cesium loadings from $40 \mathrm{mg} / \mathrm{kg}$ to nearly $71 \mathrm{~g} / \mathrm{kg}$, depending on the initial concentration of cesium. The successful application of granular KCoCF in columnar form to high-pH Loviisa supernate apparently required the $\mathrm{pH}$ to be reduced to 12 or lower. These data illustrate graphically the necessity for column studies to be performed in order to verify material stability and cesium loading characteristics for specific supernates.

\subsection{POTENTIAL APPLICATION TO HANFORD WASTES}

As described in Sect. 2.2, the concentrations of $\mathrm{Na}, \mathrm{K}$, and $\mathrm{Al}$ in the 17 double-shell tanks at Hanford ranged from 0.1 to $14.7 \mathrm{M}, 10^{-3}$ to $1.1 \mathrm{M}$, and $10^{-4}$ to $2.4 \mathrm{M}$, respectively; the Ca concentration was <0.003 $M$ in 11 of the tank supernates that were analyzed. ${ }^{5}$ The total Cs concentrations in the Hanford tanks ranged from $2.0 \times 10^{-7}$ to $6.6 \times 10^{-4} M(0.02$ to $85 \mathrm{mg} / \mathrm{L})$, corresponding to a ${ }^{137} \mathrm{Cs}$ content of 0.7 to $2500 \mu \mathrm{Ci} / \mathrm{mL}$. When these data were placed in perspective, the ranges of concentration in the supernates for the eight tanks at the MVST facility were 2.7 to $4.8 \mathrm{MNa}, 0.24$ to $2.0 \mathrm{M} \mathrm{K}$, and $10^{-5}$ to $0.6 \mathrm{M} \mathrm{Ca}$. The average $\mathrm{Al}$ concentration in the eight tanks was $5 \times 10^{-4} M$. The supernate used in this work, from MVST W-25, contained $3.9 \mathrm{MNa}, 0.36 \mathrm{MK}, 0.02 \mathrm{MAl}$, and $0.00024 \mathrm{MCa}$, and was spiked with predetermined amounts of nonradioactive $\mathrm{CsCl}$ to concentrations ranging from $1.4 \times 10^{-6}$ to $5.5 \times 10^{-3} M(0.19$ to $726 \mathrm{mg} / \mathrm{L})$. A major difference between the Hanford tank supernates and the MVST W-25 supernate is that the Na concentrations of nearly half of the former are much higher than that of the latter. However, only 3 of the 17 Hanford tank supernates have $\mathrm{K}$ concentrations greater than that of the test supernate. Results of our studies showed little deleterious effect on $\mathrm{Cs}$ adsorption by increasing $\mathrm{K}$ concentrations for $\mathrm{CST}$ and $\mathrm{KCoCF}$, but major decreases in Cs adsorption for SRR. 
In summary, the Hanford storage tanks contain supernates with a wide range of alkalinities and salt contents and, therefore, may require a variety of treatment options. Many of the tanks have very high, nearly unmeasurable pHs. Supernates with the highest alkalinities and salt contents might be amenable to treatment with SRR and/or CST. Supernates in the appropriate $\mathrm{pH}$ range ( 0 to 12.5 ) could be treated directly with granular KCoCF or a composite form such as HTiO/KCoCF. Supernates from several tanks might be

blended, if chemically compatible, to improve the effectiveness of exchangers for removing cesium by reducing the $\mathrm{pH}$ or the salt concentration.

\section{ACKNOWLEDGMENTS}

This study was supported by the U.S. Department of Energy, Office of Technology Development, Underground Storage Tank Integrated Demonstration Program, under contract DE-AC05-84OR21400 with the Martin Marietta Energy Systems, Inc.

The authors wish to thank their colleagues at Oak Ridge National Laboratory who provided assistance in making this program successful, especially J. M. Giaquinto, T. Ross, J. M. Keller, and others of the Chemistry and Analytical Sciences Division (CASD) for the chemical analyses; C. S. MacDougall of CASD for determining the composition of the granular potassium cobalt hexacyanoferrate [ $\mathrm{KCoCF}(\mathrm{gr})]$ used as a sorbent in this study; D. S. Rothrock (a Martin Marietta Energy Systems, Inc., co-op student from the University of Tennessee, Knoxville), for assisting in the preparation of the KCoCF(gr); B. J. Johnson for helping prepare the manuscript; and M. G. Stewart for editing. Technical reviewers were D. D. Lee, W. D. Bond, D. A. Bostick, and J. F. Walker, Jr. 


\section{REFERENCES}

1. M. B. Sears, J. L. Botts, R. N. Ceo, J. J. Ferrada, W. H. Griest, J. M. Keller, and R. J. Schenley, Sampling and Analysis of Radioactive Liquid Wastes and Sludges in the Melton Valley and Evaporator Storage Tanks at ORNL, ORNL/TM-11652, Oak Ridge National Laboratory, September 1990.

2. D. O. Campbell and D. D. Lee, Treatment Options and Flowsheets of ORNL Low-Level Liquid Waste Supernate, ORNL/TM-11800, Oak Ridge National Laboratory, December 1991.

3. D. D. Lee and D. O. Campbell, Treatment Requirements of Decontamination of ORNL Low-Level Liquid Waste, ORNL/TM-11799, Oak Ridge National Laboratory, October 1991.

4. D. O. Campbell, D. D. Lee, and T. A. Dillow, Development Studies for Treatment of ORNL Low-Level Liquid Waste, ORNL/TM-11798, Oak Ridge National Laboratory, November 1991.

5. N. G. Colton, R. G. Orth, and E. A. Aitken, Tank Waste Processing Analysis: Database Development, Tank-by-Tank Processing Requirements, and Examples of Pretreatment Sequences and Schedules as Applied to Hanford Double-Shell Tank Supernatant Waste-FY 1993, PNL-10134, September 1994.

6. L. A. Bray, C. D. Carlson, K. J. Carson, J. R. DesChane, R. J. Elovich, and D. E. Kurath, Initial Evaluation of Two Organic Resins and Their Ion Exchange Column Performance for the Recovery of Cesium from Hanford Alkaline Wastes, TWRSPP-93-055, Pacific Northwest Laboratory, August 1993.

7. 10 CFR 61.1988, U.S. Nuclear Regulatory Commission, "Licensing Requirement for Land Disposal of Radioactive Waste," U.S. Code of Federal Regulations.

8. A. G. Croff, ORIGEN2 - A Revised and Updated Version of the Oak Ridge Isotope Generation and Depletion Code, ORNL-5621, Oak Ridge National Laboratory, March 1986.

9. J. L. Collins, D. J. Davidson, C. W. Chase, B. Z. Egan, D. D. Ensor, R. M. Bright, and D. C. Glasgow, Development and Testing of Ion Exchangers for Treatment of Liquid Wastes at Oak Ridge National Laboratory, ORNL/TM-12315, Oak Ridge National Laboratory, March 1993.

10. W. D. Arnold, T. E. Kent, D. R McTaggart, M. W. Burgess, P. A. Taylor, and J. J. Perona, Continued Development of Decontamination Methods for Liquid Low-Level Waste at Oak Ridge National Laboratory, ORNL/CF-92-248, May 1993.

11. L. A. Bray, R. J. Elovich, and K. J. Carson, Cesium Recovery Using Savannah River Laboratory Resorcinol-Formaldehyde Ion Exchange Resin, PNL-7273, Pacific Northwest Laboratory, March 1990. 
12. M. A. Ebra, R. M. Wallace, D. D. Walker, and R. A. Wille, "Tailored Ion Exchange Resins for Combined Cesium and Strontium Removal from Soluble SRP High-Level Waste," p. 632 in The Scientific Basis for Nuclear Waste Management, ed. S. V. Topp, Elsevier, 1982.

13. J. P. Bibler, R. M. Wallace, and L. A. Bray, "Testing a New Cesium-Specific Ion Exchange Resin for Decontamination of Alkaline High-Activity Waste," pp. 747-51 in Waste Management '90, Vol. 2, ed. R. G. Post, 1990.

14. N. E. Brown, H. P. Stephens, R. G. Dosch, L. D. Bussard, and R. G. Anthony, "Crystalline Silicotitanate Ion Exchangers for Removal of Cs from Liquid Defense Radwastes," paper presented at the Efficient Separations and Processing Integrated Program, Underground Storage TankIntegrated Demonstration, Salt Lake City Meeting, Feb. 3, 1993.

15. R. G. Anthony, C. V. Philip, and R. G. Dosch, "Selective Adsorption and Ion Exchange of Metal Cations and Anions with Silico-Titanates and Layered Titanates," Waste Manage. 13, 503-12 (1993).

16. S. F. Marsh, Z. V. Svitra, and S. M. Bowen, Distribution of 14 Elements of 60 Selected Adsorbers from Two Simulant Solutions (Acid-Dissolved Sludge and Alkaline Supernate) for Hanford HLE Tank 102$S Y$, LA-12654, October 1993.

17. N. E. Brown, Sandia National Laboratories, personal communication, 1994.

18. J. Lehto, R. Harjula, E. Tusa, and A. Paavola, "Industrial Scale Removal of Cesium with Hexacyanoferrate Exchanger-Process Development," paper presented at the Waste Management '93 Symposium, Tucson, Ariz., Feb. 28-Mar. 4, 1993.

19. E. H. Tusa, A. Paavola, R. Harjula, and J. Lehto, "Industrial Scale Removal of Cesium with Hexacyanoferrate Exchanger-Process Realization and Test Run," paper presented at the Waste Management '93 Symposium, Tucson, Ariz., Feb. 28-Mar. 4, 1993.

20. W. E. Prout, E. R. Russell, and H. J. Groh, "Removal of Cesium from Aqueous Solutions by Ion Exchange," U.S. Patent 3,296,123, Jan. 3, 1967.

21. W. E. Prout, E. R. Russell, and H. J. Groh, "Ion Exchange Absorption of Cesium by Potassium Hexacyanocobalt(II) Ferrate(II)," J. Inorg. Nucl. Chem. 27, 73 (1965).

22. J. L. Collins, M. H. Lloyd, and R. L. Fellows, "The Basic Chemistry Involved in the Internal-Gelation Method of Precipitating Uranium as Determined by $\mathrm{pH}$ Measurements," Radiochim. Acta 42, 121-34 (1987).

23. J. Lehto, R. Harjula, and J. Wallace, "Adsorption of Cesium on Potassium Cobalt Hexacyanoferrate(II)," J. Radioanal. Nucl. Chem. Artic. 3(2), 297-304 (1987). 
24. J. Lehto and S. Haukka, "Separation of Cesium from Nuclear Waste Solutions with Potassium Cobalt Hexacyanoferrates(II)," Solvent Extr. Ion Exch. 5(2), 343-52 (1987).

25. J. Lehto, S. Haukka, R. Harjula, and M. Blomberg, "Mechanism of Cesium Ion Exchange on Potassium Cobalt Hexacyanoferrates(II)," J. Chem. Soc. Dalton Trans. 1990, 1007-11.

26. J. Lehto, S. Haukka, P. Koskinen, and M. Blomberg, "Thermal Decomposition of Potassium Cobalt Hexacyanoferrate(II)," Thermochim. Acta 160, 343-47 (1990).

27. J. Lehto and L. Szirtes, "Effects of Gamma Irradiation on Cobalt Hexacyanoferrate(II) Ion Exchangers," Radiat. Phys. Chem. 43(3), 261-64 (1994).

28. J. Lehto, R. Harjula, S. Haukka, and J. Wallace, "Solidification of ${ }^{137} \mathrm{Cs}$ into Potassium Cobalt Hexacyanoferrate Ion Exchanger," in Proceedings of the 1989 Joint International Waste Management Conference, October 22-28, 1989, Kyoto, Japan, Vol. 1, p. 367. 



\section{Appendix A}

\section{REMOVAL OF ${ }^{137}$ Cs FROM SUPERNATE AT THE LOVIISA NUCLEAR POWER STATION IN HELSINKI, FINLAND}

A successful industrial plant-scale demonstration, showing that granular $\mathrm{KCoCF}$ can be used in columns on a large scale to remove cesium from alkaline supernate with a high salt content $(2.6 \mathrm{MNa}$, 0.26 M K, and 5.6 MB), was recently conducted (1991-1992) at the Loviisa Nuclear Power Station (LNPS) in Helsinki, Finland..$^{18,19,23-28}$ Before the demonstration began at LNPS in October 1991, the volume of evaporator-concentrate supernate to treat totaled 143,000 gal, which was about $41 \%$ of the storage tank capacity. The total salt content of the supernate was $240 \mathrm{~g} / \mathrm{L}$. The ${ }^{137} \mathrm{Cs}$ concentration of the supernate was fairly low (only $0.01 \mathrm{mCi} / \mathrm{L}$ ); from this value, the estimated concentration of the total cesium was $2.6 \times 10^{-9} \mathrm{M}$. The $\mathrm{Na} / \mathrm{Cs}$ and $\mathrm{K} / \mathrm{Cs}$ mol ratios were $1.0 \times 10^{9}$ and $1.0 \times 10^{8}$, respectively. These ratios are much larger than those of the Hanford and ORNL supernates (see Sect. 2.2). In the demonstration, $253 \mathrm{~m}^{3}$ $(66,700 \mathrm{gal})$ of supernate was treated. A volume reduction factor of over 10,000 was achieved, as calculated by the liquid/ ion-exchanger volume ratio. The Cs decontamination factor was $\sim 2000$.

The full-scale system for cesium removal at LNPS is called the IVO-CsTreat System. ${ }^{19}$ The treatment steps performed were: (1) the $\mathrm{pH}$ of the supernate (while in the storage tank) was adjusted with concentrated nitric acid from 13.7 to a range between 11.5 and 12 ; (2) the adjusted supernate was left in the tank for several weeks to allow particulates to settle; (3) the supernate was pumped through $0.2-\mu \mathrm{m}$ cartridge filters to remove the solid fines to prevent column fouling; (4) the filtered supernate was passed through 8-L ionexchange columns (in series) to remove the cesium; and (5) the loaded columns were washed, dried, sealed, and placed into concrete blocks, 12 columns per block. The concrete blocks will be disposed of in a bedrock repository at a depth of $100 \mathrm{~m}$ at a nearby location.

Two stainless steel columns ( $60 \mathrm{~cm}$ long and $14 \mathrm{~cm}$ in diameter) were used in series. Each column contained $4.8 \mathrm{~kg}$ of granular KCoCF (grain size, 0.3 to $0.85 \mathrm{~mm}$ ) with a bed volume (BV) of $8 \mathrm{~L}$ and a bed depth of $52 \mathrm{~cm}$. The flow rate used was $80 \mathrm{~L} / \mathrm{h}\left(0.52 \mathrm{~L} \mathrm{~h}^{-1} \mathrm{~cm}^{-2}\right)$. In the test, about $20,000 \mathrm{BV}(160,000 \mathrm{~L}$ or $42,000 \mathrm{gal}$ ) was treated at $0.1 \%$ cesium breakthrough with the first column. At this point, the decontamination factor (DF) for the treated supernate was 2000. At $1 \%$ breakthrough, about 24,500 BV $(196,000 \mathrm{~L}$ or $52,000 \mathrm{gal})$ were treated. The initial concentration of ${ }^{137} \mathrm{Cs}$ in the supernate was $0.01 \mu \mathrm{Ci} / \mathrm{mL}$. During most of the cesium loading period, the level of ${ }^{137} \mathrm{Cs}$ activity in the column effluent was $1 \times 10^{-6} \mathrm{mCi} / \mathrm{L}$. At $1 \%$ breakthrough, $\sim 2 \mathrm{Ci}^{137} \mathrm{Cs}(-23 \mathrm{mg})$ was loaded on the $\mathrm{KCoCF}$. If it is assumed that the supernate contained only fission product cesium, then the total mass of cesium removed would be in the 
range of 55 to $70 \mathrm{mg}$. The effective column loading of granular $\mathrm{KCoCF}$ at $1 \%$ breakthrough was $<16 \mathrm{mg}$ $\mathrm{Cs} / \mathrm{kg}$.

Batch tests, ${ }^{24}$ laboratory-scale column tests, ${ }^{18}$ and pilot-scale column tests ${ }^{18,19}$ were conducted prior to the industrial plant-scale demonstration. In the batch tests, $20-\mathrm{mL}$ samples of supernate $(\mathrm{pH} \mathrm{13})$ were mixed with $0.2-\mathrm{g}$ samples of $\mathrm{KCoCF}$ (grain size, 0.07 to $0.14 \mathrm{~mm}$ ) for $20 \mathrm{~h}$ at room temperature. A cesium $\mathrm{K}_{\mathrm{d}}$ value of $10^{4} \mathrm{~mL} / \mathrm{g}$ was obtained. In addition to granular $\mathrm{KCoCF}$, other cesium-selective ion exchangers also were tested. The results confirmed that $\mathrm{KCOCF}$ was the most effective exchanger for removing cesium.

Laboratory-scale column tests were conducted with granular KCoCF. The bed volume and bed depth were $2 \mathrm{~mL}$ ( $1.2 \mathrm{~g} \mathrm{KCoCF})$ and $10.2 \mathrm{~cm}$, respectively; the inside diameter of the column was $0.5 \mathrm{~cm}$. Before the supernate was pumped to the columns, the $\mathrm{pH}$ was adjusted to 11.5 and the solid fines were removed with a $0.2-\mu \mathrm{m}$ filter. In column tests using 0.32 to $0.85 \mathrm{~mm} \mathrm{KCoCF}$ and a flow rate of $18 \mathrm{BV} / \mathrm{h}\left(0.18 \mathrm{~L} \mathrm{~h}^{-1} \mathrm{~cm}^{-2}\right)$, the breakthrough point at $1 \%$ occurred at $\sim 2000 \mathrm{BV}$. For similarly conducted tests using KCoCF particles in the range of 0.14 to $0.32 \mathrm{~mm}$, cesium breakthrough at $1 \%$ was a factor of 3 higher $(\sim 600 \mathrm{BV})$. Using 0.32 to $0.85 \mathrm{~mm} \mathrm{KCoCF}$, cesium breakthroughs at $1 \%$ occurred at 2800 and $1600 \mathrm{BV}$ in tests with flow rates of $10 \mathrm{BV} / \mathrm{h}\left(0.10 \mathrm{~L} \mathrm{~h}^{-1} \mathrm{~cm}^{-2}\right)$ and $34 \mathrm{BV} / \mathrm{h}\left(0.35 \mathrm{~L} \mathrm{~h}^{-1} \mathrm{~cm}^{-2}\right)$, respectively.

Each of the columns used in the pilot-scale tests ${ }^{18,19}$ had an inside diameter of $2.54 \mathrm{~cm}$. The $0.15-\mathrm{L}$ columns had a KCoCF bed depth of $30 \mathrm{~cm}$. About $90 \mathrm{~g}$ of granular $\mathrm{KCoCF}$ was used. For a flow rate of $11 \mathrm{BV} / \mathrm{h}\left(0.34 \mathrm{~L} \mathrm{~h}^{-1} \mathrm{~cm}^{-2}\right), \sim 18,000 \mathrm{BV}$ of supernate were treated at $1.0 \%$ breakthrough with $\mathrm{KCoCF}$ having a particle size range of 0.32 to $0.85 \mathrm{~mm}$. These test conditions were similar to those used in the industrialscale test. In that test, $24,500 \mathrm{BV}$ of supernate were treated. At a faster flow rate of $22 \mathrm{BV} / \mathrm{h}\left(0.67 \mathrm{~L} \mathrm{~h}^{-1}\right.$ $\mathrm{cm}^{-2}$ ) in the pilot-scale tests, only $10,000 \mathrm{BV}$ was treated. At $0.1 \%$ cesium breakthrough, about 8,000 and $4,000 \mathrm{BV}$ were treated at flow rates of 11 and $22 \mathrm{BV} / \mathrm{h}$, respectively. Prior to testing, the $\mathrm{pH}$ of the supernate was decreased from 13.7 to between 12 and 11.5. The upper limit of 12 was chosen to avoid any dissolution of the exchanger; the lower limit, 11.5, was selected to avoid precipitation of borates from the solution. Subsequently, the supernate was filtered through a $0.2-\mu \mathrm{m}$ filter cartridge to remove any solid fines that might clog the column.

The KCoCF used in the industrial-scale and pilot-plant-scale experiments had the composition $\mathrm{K}_{1.76} \mathrm{Co}_{1.12} \mathrm{Fe}(\mathrm{CN})_{6}$. Of the ten compositions of granular $\mathrm{KCoCF}$ materials prepared, ${ }^{25}$ this composition was determined to be the most suitable form for column use. The materials were prepared by modifying the general preparation method developed by Prout et al. ${ }^{20,21}$ A method to produce granular $\mathrm{K}_{1.76} \mathrm{Co}_{1.12} \mathrm{Fe}(\mathrm{CN})_{6}$ on an industrial scale was developed, a facility to produce it was constructed, and large quantities were 
prepared. Prout's granular $\mathrm{KCoCF}$ had the composition $\mathrm{K}_{1.60} \mathrm{Co}_{1.4} \mathrm{Fe}(\mathrm{CN})_{6}$. In the preparations, the $\mathrm{KCoCF}$ made by both groups used a $\mathrm{Co}\left(\mathrm{NO}_{3}\right)_{2} / \mathrm{K}_{4} \mathrm{Fe}(\mathrm{CN})_{6}$ mol ratio of $\sim 1.4$ in the preparative procedure.

The gamma irradiation stability of the $\mathrm{KCoCF}^{27}$ was determined at LNPS by exposing samples to a ${ }^{60} \mathrm{Co}$ source at a dose rate of $17 \mathrm{kGy} / \mathrm{h}$. Samples receiving doses of 2.1 and $5.0 \mathrm{MGy}$ were examined by $\mathrm{X}$-ray diffractometry and IR spectrometry and were found to be structurally unaltered when compared with samples of nonirradiated KCoCF. Batch equilibration tests with the samples also showed that the gamma irradiation had no adverse effect on the sorption of cesium by the KCoCF. These data suggested that a loading of ${ }^{137} \mathrm{Cs}$ on $\mathrm{KCoCF}$ can be at least $0.8 \mathrm{Ci} / \mathrm{kg}$, and that in an actual ion-exchange process it could be much higher.

The thermal decomposition properties of $\mathrm{KCoCF}$ were also determined. ${ }^{26}$ At $170^{\circ} \mathrm{C}, \mathrm{KCoCF}$ loses water of hydration; and at $230^{\circ} \mathrm{C}$, it begins to decompose. The cyanide groups volatilize in the range of 230 to $350^{\circ} \mathrm{C}$, and potassium carbonate and iron and cobalt oxides are formed.

Lehto et al. also conducted a study of the removal of ${ }^{137} \mathrm{Cs}$ from $\mathrm{KCoCF}$ with groundwater. ${ }^{28}$ The groundwater leachant, which was obtained from the Loviisa NPP area, was contacted with concrete for 2 weeks before use. The $\mathrm{pH}$ of the leachant rose to 12.4 . Ten-milliliter volumes of the leachant were shaken for 8 months with $1-\mathrm{g}$ samples of $\mathrm{KCoCF}$ loaded with ${ }^{134} \mathrm{Cs}$. Every month, the leachates were separated from the exchangers and new leachant was added. The ${ }^{134} \mathrm{Cs}$ measurements in the leachates were always about the same. The fraction removed each month was $4 \times 10^{-5}$ of the original ${ }^{134} \mathrm{Cs}$ activity in the exchanger. Assuming that this is a constant rate, 1000 years would be required to elute $50 \%$ of the original activity in the exchanger. In fact, since the half-life of ${ }^{137} \mathrm{Cs}$ is only $30.17 \mathrm{y}$, about $99.9 \%$ of the ${ }^{137} \mathrm{Cs}$ would decay to stable isotopes in $302 \mathrm{y}$ (ten half-lives). For a $10^{6}-\mathrm{Ci}{ }^{137} \mathrm{Cs}$ source, only $977 \mathrm{Ci}$ would remain after $302 \mathrm{y}$. After an additional ten-half-life period, the activity would decrease to only $1 \mathrm{Ci}$. 

Appendix B

\section{PREPARATION OF GRANULAR POTASSIUM COBALT HEXACYANOFERRATE(I)}

The granular KCoCF used in this study was prepared by slightly modifying the patented procedure of W. F. Prout et al. ${ }^{20,21}$ The $\mathrm{KCoCF}$ was made by slowly adding $200 \mathrm{~mL}$ of $0.5 M \mathrm{~K}_{4} \mathrm{Fe}(\mathrm{CN})_{6}$ containing $1.8 \times 10^{-3} \mathrm{M}$ acetic acid to $480 \mathrm{~mL}$ of $0.3 \mathrm{MCo}\left(\mathrm{NO}_{3}\right)_{2}$ while stirring. The order of addition is important. The reactants were chilled at ice-bath temperatures $\left(0\right.$ to $\left.5^{\circ} \mathrm{C}\right)$. The addition required $20 \mathrm{~min}$, and the reaction mixture was subsequently stirred an additional $10 \mathrm{~min}$. The $\mathrm{pH}$ of the reaction solution was measured continuously. The acetic acid, in the presence of the potassium ion, acted as a buffer; the final $\mathrm{pH}$ of the reaction solution was 5.3. The formation of stoichiometric $\mathrm{KCoCF}$ is represented by the following equation:

$$
\mathrm{K}_{4} \mathrm{Fe}(\mathrm{CN})_{6}+\mathrm{Co}\left(\mathrm{NO}_{3}\right)_{2} \rightarrow \mathrm{K}_{2} \mathrm{CoFe}(\mathrm{CN})_{6}+2 \mathrm{KNO}_{3} .
$$

The reaction mixture slurry was then divided equally among four $250-\mathrm{mL}$ large-mouth polyethylene centrifuge bottles and centrifuged for $15 \mathrm{~min}$ at $3000 \mathrm{rpm}$. The clarified solutions were decanted, and the $\mathrm{KCoCF}$ solids were washed three times with $100 \mathrm{~mL}$ of deionized water. Each time, the solids were first resuspended with a vortex mixer for $5 \mathrm{~min}$ and then centrifuged for $10 \mathrm{~min}$. The decanted liquids were clear and colorless. Additional water washes caused the KCoCF solids to peptize and become difficult to separate.

The results of one of the preparations are described as follows: The centrifuged wet solids (206.4 $\mathrm{g}$ ) were transferred to a Pyrex glass tray for drying. About $4 \mathrm{~g}$ was lost in the transfer. The thickness of the wet solid layer was about 0.5 to $1 \mathrm{~cm}$ for the best drying results. The solids were dried at $115^{\circ} \mathrm{C}$ for $15 \mathrm{~h}$, not including a 3-h ramp heating period. A long ramp time was needed to vaporize the free liquid without boiling it. Boiling the liquid in the wet solids caused splattering and increased the amount of fine particles. After being dried, the $\mathrm{KCoCF}$ solids were cooled to room temperature and weighed. The solids weighed $37.04 \mathrm{~g}$, which was about $18 \%$ of the initial mass of centrifuged wet solids.

In the next step, the solids were gently crushed by hand with a mortar and pestle and sieved to the desired size (150 to $420 \mu \mathrm{m})$. The granular KCoCF was then placed on a large 100-mesh sieve and rinsed with deionized water to remove any adhering fine particles $(<150 \mu \mathrm{m})$. Afterward, the material was placed in a clean Pyrex tray and dried at $70^{\circ} \mathrm{C}$ for a few hours. About $25 \mathrm{~g}$ of the 150 - to $420-\mu \mathrm{m}$ granular KCoCF was obtained. The "slow-pour" density, as determined by slowly pouring $\sim 10 \mathrm{~mL}$ of granular KCoCF into a tared graduated cylinder and weighing, was $0.6 \mathrm{~g} / \mathrm{mL}$. Interestingly, the densities of the granular $\mathrm{KCoCF}$ tested by both Prout and Lehto were also $0.6 \mathrm{~g} / \mathrm{mL}$. 
A key to scaling up this preparation is adding one volume of $0.5 M \mathrm{~K}_{4} \mathrm{Fe}(\mathrm{CN})_{6}$ to 2.4 volumes of $0.3 M$ $\mathrm{Co}\left(\mathrm{NO}_{3}\right)_{2}$ at $\sim 5^{\circ} \mathrm{C}$ over a limited time and buffering with acetic acid to a $\mathrm{pH}$ of 5.3. The Prout patent called for the use of sodium acetate buffer. By using acetic acid as the buffer, no sodium ions are introduced into the KCoCF crystalline structure. The contact time between the reactants is important because it affects the ratio of potassium to cobalt in the potassium cobalt hexacyanoferrate product $\left(\mathrm{K}_{2-x} \mathrm{Co}_{1+x} \mathrm{Fe}(\mathrm{CN})_{6}\right)$; the longer the reaction time, the less potassium and more cobalt are present in the structure. Based on X-ray diffraction and energy-dispersive $\mathrm{X}$-ray analyses, the granular $\mathrm{KCOCF}$ being used in the present study at ORNL has the composition $\mathrm{K}_{1.21} \mathrm{Co}_{1.34} \mathrm{Fe}(\mathrm{CN})_{6}$.

Researchers at LNPS determined that stoichiometric and near-stoichiometric granular potassium cobalt hexacyanoferrate readily degraded in high-pH supernatant solutions. Of the ten granular KCoCF materials they prepared, the one with the most stable structure, which was used in their column studies, had the composition $\mathrm{K}_{1.76} \mathrm{Co}_{1.12} \mathrm{Fe}(\mathrm{CN})_{6}$.

Prout et al. ${ }^{20,21}$ found that the highest cesium capacities for granular $\mathrm{KCoCF}$ were obtained in highly alkaline and acidic solutions with high $\mathrm{NaNO}_{3}$ solutions, as opposed to neutral solutions. 
ORNL/TM-12938

\section{INTERNAL DISTRIBUTION}

$\begin{aligned} \text { 1. } & \text { K. K. Anderson } \\ 2 . & \text { E. C. Beahm } \\ \text { 3. } & \text { W. D. Bond } \\ 4 . & \text { D. A. Bostick } \\ \text { 5. } & \text { C. W. Chase } \\ 6 . & \text { E. D. Collins } \\ 7-16 . & \text { J. L. Collins } \\ 17 . & \text { A. G. Croff } \\ \text { 18. } & \text { D. J. Davidson } \\ \text { 19. } & \text { S. M. DePaoli } \\ 20-29 . & \text { B. Z. Egan } \\ 30 . & \text { C. W. Forsberg } \\ 31 . & \text { R. D. Hunt } \\ 32 . & \text { R. T. Jubin } \\ 33 . & \text { J. M. Keller } \\ 34 . & \text { T. E. Kent } \\ 35 . & \text { D. D. Lee } \\ 36 . & \text { A. P. Malinauskas } \\ 37 . & \text { A. J. Mattus }\end{aligned}$
38. L. E. McNeese
39. C. P. McGinnis
40. B. A. Moyer
41. J. E. Mrochek
42. D. E. Reichle
43. S. M. Robinson
44. M. B. Sears
45. B. B. Spencer
46. D. P. Stevens
47. J. Trabalka
48. J. F. Walker
49. J. S. Watson
50-51. ORNL Laboratory Records
52. ORNL Laboratory Records, RC
53. ORNL Patent Section
54. Y-12 Technical Library
Document Reference Center
55. Central Research Library

\section{EXTERNAL DISTRIBUTION}

56. R. G. Anthony, Dept. of Chemical Engineering, Texas A \& M University, College Station, TX 77843-3122

57. M. Attrep, Jr., Los Alamos National Laboratory, P.O. Box 1663, MS J514, Los Alamos, NM 87545

58. D. L. Biancosino, Department of Energy, Trevion II, 19901 Germantown Road, Germantown, MD 20874

59. J. P. Bibler, Westinghouse Savannah River Company, Savannah River Technical Center, Building 773-A, B-132, Aiken, SC 29808

60. L. A. Bray, Pacific Northwest Laboratory, M \& CS Center-Chem PMC Syst Section, Battelle Boulevard, P.O. Box 999, Richland, WA 99352

61. G. N. Brown, Pacific Northwest Laboratory, Battelle Boulevard, P.O. Box 999, Richland, WA 99352

62. N. E. Brown, Sandia National Laboratories, Department 6624, Albuquerque, NM 87185

63. N. G. Colton, Pacific Northwest Laboratory, Battelle Boulevard, P.O. Box 999, MS P830, Richland, WA 99352

64. A. Clearfield, Department of Chemistry, Texas A \& M University, College Station, TX 77843 
65. T. A. Fryberger, Department of Energy, Trevion II, 19901 Germantown Road, Germantown, MD 20585

66. D. W. Geiser, Department of Energy, Trevion II, 19901 Germantown Road, Germantown, MD 20585

67. S. M. Gibson, Department of Energy, Trevion II, 19901 Germantown Road, Germantown, MD 20585

68. T. Kafka, 3M Company, 3M Center, 209-1 W-24, St. Paul, MN 55144-1000

69. R. L. Gilchrist, Westinghouse Hanford Company, P.O. Box 1970, L5-63, Richland, WA 99352

70. M. J. Gula, Eichrom Industries, Inc., 8205 S. Cass Avenue, Suite 107, Darien, IL 60559

71. R. D. Korynta, Department of Energy, Oak Ridge Operations, P.O. Box 2001, Oak Ridge, TN 37831-8620

72. W. L. Kuhn, Pacific Northwest Laboratory, Battelle Boulevard, P.O. Box 999, Richland, WA 99352

73. D. E. Large, Scientific Ecology Group, Inc., P.O. Box 2530, 1560 Bear Creek Rd., Oak Ridge, TN 37830

74. G. J. Lumetta, Pacific Northwest Laboratory, Battelle Boulevard, P.O. Box 999, P7-25, Richland, WA 99352

75. S. F. Marsh, Sandia National Laboratories, P.O. Box 1663, MS E501, Los Alamos, NM 87545

76. D. W. Marshall, Westinghouse Idaho Nuclear Company, Inc., P.O. Box 4000, Idaho Falls, ID 83415

77. S. Marchetti, Parsons Environmental Services, Inc., 4701 Hedgemore Dr., Charlotte, NC 28209

78. J. O. Moore, Oak Ridge Technical Program Officer, Department of Energy, Oak Ridge Operations Office, P.O. Box 2001, Oak Ridge, TN 37831-8620

79. L. L. Nenninger, SAIC, 555 Quince Orchard Road, Suite 500, Gaithersburg, MD 20878

80. J. Noble-Dial, Department of Energy, Oak Ridge Operations, P.O. Box 2001, Oak Ridge, TN 37831-8620

81. M. J. Quadrel, Pacific Northwest Laboratory, Battelle Boulevard, P.O. Box 999, Richland, WA 99352

82. R. K. Quinn, Pacific Northwest Laboratory, Battelle Boulevard, P.O. Box 999, Richland, WA 99352

83. J. L. Swanson, Pacific Northwest Laboratory, Battelle Boulevard, MS P7-25, P. O. Box 999, Richland, WA 99352

84. W. L. Tamosaitas, Westinghouse Savannah River Company, Savannah River Site, Aiken, SC 29801

85. Office of Assistant Manager, Energy Research and Development, DOE-ORO, P.O. Box 2008, Oak Ridge, TN 37831-6269

86-87. Office of Scientific and Technical Information, P.O. Box 62, Oak Ridge, TN 37831 